\title{
Terrigenous sediment supply along the Chilean continental margin: modern regional patterns of texture and composition
}

Received: 17 April 1998 / Accepted: 2 September 1998

\begin{abstract}
The regional patterns of texture and composition of modern continental slope and pelagic sediments off Chile between $25^{\circ} \mathrm{S}$ and $43^{\circ} \mathrm{S}$ reflect the latitudinal segmentation of geological, morphological, and climatic features of the continental hinterland. Grain-size characteristics are controlled by the grain-size of source rocks, the weathering regime, and mode of sediment input (eolian off northern Chile vs fluvial further south). Bulk-mineral assemblages reveal a low grade of maturity. Regional variations are governed by the source-rock composition of the different geological terranes and the relative source-rock contribution of the Coastal Range and Andes, as controlled by the continental hydrology. The relative abundance of clay minerals is also predominantly influenced by the source-rock composition and partly by continental smectite neoformation. Latitudinal variations of illite crystallinities along the Chilean continental slope (and west of the Peru-Chile trench) clearly reflect modifications of the weathering regime which correspond to the strong climatic zonation of Chile.
\end{abstract}

Key words Chile - Modern continental margin sedimentation - Marine sediments · Clastic sediments · Granulometry - Mineralogy $\cdot$ Clay mineralogy

\section{Introduction}

The Chilean continental margin provides an excellent opportunity to study recent terrigenous surface sediments in relation to the continental hinterland. Chile reveals a strong geological and morphological latitudinal segmentation. Extreme climatic gradients between northern and southern

F. Lamy $(\bowtie) \cdot$ D. Hebbeln · G. Wefer

Fachbereich Geowissenschaften, Universität Bremen,

Postfach 3304 40, D-28334 Bremen, Germany

Fax: ++49 4212183114

e-mail: frankl@allgeo.uni-bremen.de
Chile result in equivalent variations of the continental hydrology. Additionally, bathymetric features of the shelf, slope, and trench vary significantly. All these factors can influence the composition and texture of modern continental slope and pelagic sediments west of the Peru-Chile trench.

The purpose of this study was to investigate regional distribution patterns of mineralogical and grain-size parameters in relation to source rocks, weathering regimes, modes of sediment input, and types of deposition. We show that the mineralogy of surface samples along the Chilean continental margin is primarily controlled by relative sourcerock contributions of the different geological terranes in Chile and only subordinately by varying weathering regimes. Climate strongly influences the mode of sediment input. Some pelagic samples from areas west of the Peru-Chile trench were studied in order to show whether the trench displays a barrier for the seaward transport of terrigenous sediments and whether regional distribution patterns of sedimentological parameters can also be observed further offshore.

Regional sedimentological studies in the investigated segment of the South American continental margin are sparse. They include primarily investigations of the provenance and petrofacies of trench sands (Thornburg and Kulm 1987b) and river sands (Baba 1986). For adjacent areas examinations of surface sediments exist for the continental margin off Peru and northern Chile (Krissek et al. 1980; Rosato and Kulm 1981; Scheidegger and Krissek 1982) and shelf areas of the Chilean archipelago (Siegel et al. 1981). Additionally, terrigenous sediments, recovered during ODP leg 112 on the Peruvian continental margin (Clayton and Kemp 1990) and ODP leg 141 near the Chile triple junction (Kurnosov et al. 1995), were analyzed concerning mainly the clay mineralogy.

\section{Study area}

The study area stretches from approximately $25^{\circ} \mathrm{S}$ to $43^{\circ} \mathrm{S}$ along the continental margin of Chile in the Southeast Pacific (Fig. 1). Surface samples were recovered from the 


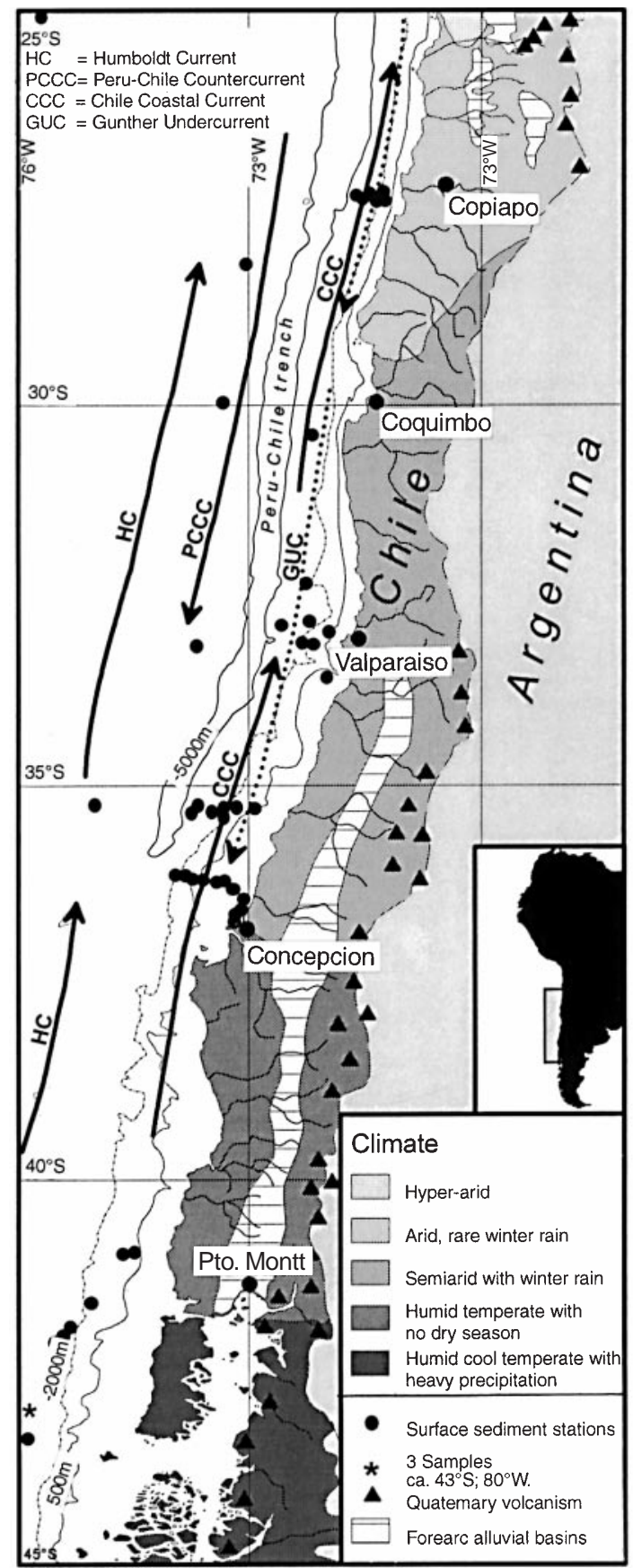

Fig. 1 Map of the study area with location of sample stations and principal oceanographic features (after Strub et al. 1998). Distribution of Quaternary volcanism and forearc alluvial basins (after Thornburg and Kulm 1987b) reflect three main geological and morphological latitudinal segments within the investigation area: north of $27.5^{\circ} \mathrm{S}, 27.5^{\circ}$ to $33^{\circ} \mathrm{S}$ and south of $33^{\circ} \mathrm{S}$. Additionally continental hydrology and climatic zonation (after Heusser 1984) are presented

continental slope in transects at $27^{\circ} \mathrm{S}, 33^{\circ} \mathrm{S}, 35^{\circ} \mathrm{S}, 36^{\circ} \mathrm{S}$, and $41 \mathrm{~S}^{\circ}$ to $43^{\circ} \mathrm{S}$. At the $36^{\circ} \mathrm{S}$ profile additional samples were taken on the shelf and the uppermost continental slope while the remaining transects cover the slope at water depths between 500 and $3700 \mathrm{~m}$ (Table 1). Additionally, samples were taken west of the Peru-Chile trench between $25^{\circ} \mathrm{S}$ and $43^{\circ} \mathrm{S}$.
Marine geological setting and bathymetry

Along the active continental margin of Chile the Nazca Plate is subducted beneath the South American continent. In the study area (Fig. 1) the Peru-Chile trench can be divided into three morphologic segments which are separated by tectonic discontinuities (Thornburg and Kulm 1987a, b). North of $27.5^{\circ} \mathrm{S}$ the trench reaches its greatest depth of up to $8000 \mathrm{~m}$. Because sediment infill is very thin, from $27.5^{\circ} \mathrm{S}$ to $33^{\circ} \mathrm{S}$ a continuous sediment wedge partially fills the trench up to water depths of approximately $5500 \mathrm{~m}$ (Scholl et al. 1970). Further south the sediment fill increases markedly up to $2 \mathrm{~km}$ thickness. South of $38^{\circ} \mathrm{S}$ the structural trench is completely buried. The maximum water depth therefore diminishes gradually to approximately $4500 \mathrm{~m}$ at $37^{\circ} \mathrm{S}$ and $<4000 \mathrm{~m}$ south of $40^{\circ} \mathrm{S}$.

The continental slope is generally steep reaching maximum inclinations of $10-15^{\circ}$ in its lower part. The ascent from the trench is often broken by structural troughs which form sediment traps (Scholl et al. 1970). Submarine canyons beginning at the shelf break occur off the mouth of major rivers. They are sparse to absent north of $33^{\circ} \mathrm{S}$ but become more frequent further south where big submarine fans are developed on the lower continental slope and in the trench (Thornburg and Kulm 1987a, b). North of $33^{\circ} \mathrm{S}$ the shelf is extremely narrow averaging only $10 \mathrm{~km}$; further south it widens to an average of 20-30 km and reaches up to $150 \mathrm{~km}$ width south of $42^{\circ} \mathrm{S}$ (Scholl et al. 1970). The shelf break is generally located at water depths between 150 and $200 \mathrm{~m}$.

\section{Oceanographic setting}

Subantarctic surface water is transported northward by the Humboldt Current (HC; Fig. 1), which originates from the Antarctic Circumpolar Current (ACC; Strub et al. 1998). The ACC approaches South America at approximately $40-45^{\circ} \mathrm{S}$ and branches here into the $\mathrm{HC}$ and the southwardflowing Cape Horn Current (Boltovskoy 1976). The HC occurs offshore of the poleward Peru-Chile Countercurrent (PCCC; Fig. 1), which transports Subtropical Surface Water to the south. Inshore of the PCCC the Chile Coastal Current (CCC; Fig. 1) flows toward the equator (Strub et al. 1998).

Beneath these surface currents occurs the poleward-directed Gunther Undercurrent (Equatorial Subsurface Water) located mainly over the continental slope and outer shelf (Fig. 1). Maximum velocities occur between 150 and $300 \mathrm{~m}$ water depth (e.g., Johnson et al. 1980). Equatorial Subsurface Water reaches the surface during coastal upwelling. Upwelling favorable winds occur in northern and central Chile north of $35^{\circ} \mathrm{S}$ throughout the year but are restricted to the austral summer between $35^{\circ} \mathrm{S}$ and $42^{\circ} \mathrm{S}$. South of $42^{\circ} \mathrm{S}$ prevailing onshore blowing westerlies prevent upwelling (Strub et al. 1998).

Below 400-600 m water depth Antarctic Intermediate Water flows toward the equator which is underlain by sluggish southward-flowing Pacific Deep Water (e.g., Shaffer et 
Table 1 Bulk grain size and silt grain-size data of surface samples from the Chilean continental margin between $25^{\circ} \mathrm{S}$ and $43^{\circ} \mathrm{S}$.

\begin{tabular}{|c|c|c|c|c|c|c|c|c|c|}
\hline $\begin{array}{l}\text { Sample } \\
\text { station* }\end{array}$ & $\begin{array}{l}\text { Latitude } \\
\text { south }\end{array}$ & $\begin{array}{l}\text { Longitude } \\
\text { west }\end{array}$ & $\begin{array}{l}\text { Water } \\
\text { depth }\end{array}$ & $\begin{array}{l}\text { Sand }^{\mathrm{a}} \\
(\mathrm{wt}-\%)\end{array}$ & $\begin{array}{l}\text { Siltt }^{\mathrm{a}} \\
(\mathrm{wt}-\%)\end{array}$ & $\begin{array}{l}\text { CIaya }^{a} \\
(w t-\%)\end{array}$ & $\begin{array}{l}\text { Median'b } \\
\text { (phi) }\end{array}$ & $\begin{array}{l}\text { Sorting } \\
\text { (phi) }\end{array}$ & Skewness $^{\text {b }}$ \\
\hline \multicolumn{10}{|l|}{$27^{\circ} \mathrm{S}$ transect } \\
\hline GeoB 3374-1 & $27^{\circ} 28.4^{\prime}$ & $71^{\circ} 10.3^{\prime}$ & $1352 \mathrm{~m}$ & 13.25 & 71.67 & 15.08 & 5.21 & 1.11 & 0.41 \\
\hline GeoB 3373-1 & $27^{\circ} 30.1^{\prime}$ & $71^{\circ} 12.4^{\prime}$ & $1580 \mathrm{~m}$ & 16.85 & 70.28 & 12.87 & 5.13 & 1.06 & 0.42 \\
\hline GeoB $3375-2$ & $27^{\circ} 28.0^{\prime}$ & $71^{\circ} 15.1^{\prime}$ & $1948 \mathrm{~m}$ & 7.40 & 71.85 & 20.75 & 5.50 & 1.12 & 0.30 \\
\hline GeoB 3376-2 & $27^{\circ} 28.0^{\prime}$ & $71^{\circ} 21.7^{\prime}$ & $2437 \mathrm{~m}$ & 13.29 & 67.17 & 19.54 & 5.46 & 1.15 & 0.31 \\
\hline GeoB 3378-2 & $27^{\circ} 30.0^{\prime}$ & $71^{\circ} 30.0^{\prime}$ & $3286 \mathrm{~m}$ & 5.67 & 65.74 & 28.58 & 6.02 & 1.30 & 0.16 \\
\hline GeoB 3377-1 & $27^{\circ} 28.0^{\prime}$ & $71^{\circ} 31.5^{\prime}$ & $3576 \mathrm{~m}$ & 8.07 & 69.69 & 22.24 & 5.70 & 1.22 & 0.26 \\
\hline \multicolumn{10}{|l|}{$30^{\circ} \mathrm{S}$ transect } \\
\hline GeoB 3368-4 & $30^{\circ} 21.6^{\prime}$ & $71^{\circ} 57.5^{\prime}$ & $3240 \mathrm{~m}$ & 3.66 & 65.82 & 30.52 & 6.28 & 1.31 & 0.07 \\
\hline GeoB 3371-1 & $30^{\circ} 21.6^{\prime}$ & $72^{\circ} 01.1^{\prime}$ & $3458 \mathrm{~m}$ & - & - & - & - & - & - \\
\hline \multicolumn{10}{|l|}{$3^{\circ} \mathrm{S}$ transect } \\
\hline GeoB 3311-2 & $33^{\circ} 36.4^{\prime}$ & $72^{\circ} 02.8^{\prime}$ & $471 \mathrm{~m}$ & 68.97 & 20.03 & 11.00 & 4.94 & 1.36 & 0.56 \\
\hline GeoB 3301-2 & $33^{\circ} 08.8^{\prime}$ & $71^{\circ} 58.9^{\prime}$ & $970 \mathrm{~m}$ & 20.52 & 58.90 & 20.58 & 5.42 & 1.26 & 0.35 \\
\hline GeoB 3302-2 & $33^{\circ} 13.1^{\prime}$ & $72^{\circ} 05.2^{\prime}$ & $1502 \mathrm{~m}$ & 9.59 & 61.84 & 28.57 & 5.98 & 1.30 & 0.16 \\
\hline GeoB 3303-1 & $33^{\circ} 12.4^{\prime}$ & $72^{\circ} 10.5^{\prime}$ & $1983 \mathrm{~m}$ & 4.72 & 58.02 & 37.26 & 6.54 & 1.30 & 0.03 \\
\hline GeoB 3304-3 & $32^{\circ} 53.4^{\prime}$ & $72^{\circ} 11.5^{\prime}$ & $2413 \mathrm{~m}$ & 5.75 & 57.85 & 36.40 & 6.46 & 1.24 & 0.01 \\
\hline GeoB 3365-1 & $32^{\circ} 17.1^{\prime}$ & $72^{\circ} 16.0^{\prime}$ & $2450 \mathrm{~m}$ & 18.64 & 50.20 & 31.16 & 6.59 & 1.36 & -0.08 \\
\hline GeoB 3305-2 & $32^{\circ} 51.1^{\prime}$ & $72^{\circ} 25.4^{\prime}$ & $3029 \mathrm{~m}$ & 0.71 & 52.78 & 46.51 & 7.09 & 1.12 & -0.13 \\
\hline \multicolumn{10}{|l|}{$35^{\circ} \mathrm{S}$ transect } \\
\hline GeoB 3359-1 & $35^{\circ} 13.0^{\prime}$ & $72^{\circ} 48.5^{\prime}$ & $680 \mathrm{~m}$ & 6.84 & 55.95 & 37.21 & 6.37 & 1.28 & -0.01 \\
\hline GeoB 3355-4 & $35^{\circ} 13.1^{\prime}$ & $73^{\circ} 07.0^{\prime}$ & $1511 \mathrm{~m}$ & 11.06 & 51.17 & 37.77 & 6.49 & 1.33 & -0.03 \\
\hline GeoB 3357-1 & $35^{\circ} 17.0^{\prime}$ & $73^{\circ} 13.2^{\prime}$ & $2103 \mathrm{~m}$ & 5.78 & 53.47 & 40.75 & 6.79 & 1.13 & -0.07 \\
\hline GeoB 3352-2 & $35^{\circ} 13.0^{\prime}$ & $73^{\circ} 19.0^{\prime}$ & $2108 \mathrm{~m}$ & 7.02 & 52.54 & 40.44 & 6.56 & 1.30 & -0.05 \\
\hline GeoB 3349-4 & $35^{\circ} 15.1^{\prime}$ & $73^{\circ} 25.2^{\prime}$ & $2471 \mathrm{~m}$ & 2.00 & 49.44 & 48.57 & 7.12 & 1.16 & -0.19 \\
\hline GeoB 3354-1 & $35^{\circ} 13.0^{\prime}$ & $73^{\circ} 29.3^{\prime}$ & $3233 \mathrm{~m}$ & 1.15 & 47.73 & 51.12 & 7.22 & 1.09 & -0.14 \\
\hline GeoB 3353-1 & $35^{\circ} 15.0^{\prime}$ & $73^{\circ} 34.6^{\prime}$ & $3749 \mathrm{~m}$ & 1.44 & 48.83 & 50.18 & 7.08 & 1.26 & -0.18 \\
\hline \multicolumn{10}{|l|}{$36^{\circ} \mathrm{S}$ transect } \\
\hline VG 2 & $36^{\circ} 40.1^{\prime}$ & $73^{\circ} 03.9^{\prime}$ & $19 \mathrm{~m}$ & 1.01 & 45.65 & 53.34 & 6.46 & 1.16 & 0.14 \\
\hline VG 7 & $36^{\circ} 36.5^{\prime}$ & $73^{\circ} 00.6^{\prime}$ & $37 \mathrm{~m}$ & 1.76 & 53.72 & 44.53 & - & - & - \\
\hline VG 9 & $36^{\circ} 34.6^{\prime}$ & $73^{\circ} 00.8^{\prime}$ & $36 \mathrm{~m}$ & - & - & - & - & - & - \\
\hline VG 18 & $36^{\circ} 30.8^{\prime}$ & $73^{\circ} 07.7^{\prime}$ & $90 \mathrm{~m}$ & 13.10 & 43.22 & 43.68 & - & - & - \\
\hline VG 21 & $36^{\circ} 29.5^{\prime}$ & $73^{\circ} 11.7^{\prime}$ & $107 \mathrm{~m}$ & 11.97 & 40.52 & 47.51 & 6.50 & 1.15 & 0.07 \\
\hline VG 26 & $36^{\circ} 25.9^{\prime}$ & $73^{\circ} 23.4^{\prime}$ & $120 \mathrm{~m}$ & 20.02 & 43.41 & 36.57 & 6.03 & 1.18 & 0.22 \\
\hline VG 32 & $36^{\circ} 23.8^{\prime}$ & $73^{\circ} 32.0^{\prime}$ & $200 \mathrm{~m}$ & 85.45 & 11.88 & 2.67 & - & - & - \\
\hline VG 34 & $36^{\circ} 23.3^{\prime}$ & $73^{\circ} 33.6^{\prime}$ & $400 \mathrm{~m}$ & 51.54 & 31.38 & 17.08 & 5.50 & 1.30 & 0.29 \\
\hline VG 36 & $36^{\circ} 22.6^{\prime}$ & $73^{\circ} 35.9^{\prime}$ & $600 \mathrm{~m}$ & 5.99 & 59.85 & 34.16 & - & - & - \\
\hline VG 40 & $36^{\circ} 20.1^{\prime}$ & $73^{\circ} 43.7^{\prime}$ & $1000 \mathrm{~m}$ & 8.10 & 55.29 & 36.62 & 6.21 & 1.22 & 0.07 \\
\hline VG 41 & $36^{\circ} 19.6^{\prime}$ & $73^{\circ} 49.1^{\prime}$ & $2000 \mathrm{~m}$ & 2.05 & 63.39 & 34.56 & - & - & - \\
\hline \multicolumn{10}{|c|}{$41 / 43^{\circ} \mathrm{S}$ transect } \\
\hline GeoB 3312-8 & $41^{\circ} 00.5^{\prime}$ & $74^{\circ} 20.2^{\prime}$ & $579 \mathrm{~m}$ & 12.75 & 57.83 & 29.43 & 5.90 & 1.21 & 0.21 \\
\hline GeoB 3313-3 & $41^{\circ} 00.0^{\prime}$ & $74^{\circ} 27.0^{\prime}$ & $851 \mathrm{~m}$ & 1.47 & 62.84 & 35.69 & 6.39 & 1.14 & 0.08 \\
\hline GeoB 3314-2 & $41^{\circ} 36.2^{\prime}$ & $74^{\circ} 58.8^{\prime}$ & $1652 \mathrm{~m}$ & 10.21 & 57.76 & 32.04 & 6.09 & 1.31 & 0.15 \\
\hline GeoB 3316-3 & $41^{\circ} 56.3^{\prime}$ & $75^{\circ} 12.8^{\prime}$ & $2575 \mathrm{~m}$ & 2.10 & 57.90 & 40.01 & 6.58 & 1.20 & -0.01 \\
\hline GeoB 3317-6 & $42^{\circ} 00.8^{\prime}$ & $75^{\circ} 18.1^{\prime}$ & $2923 \mathrm{~m}$ & 3.97 & 56.30 & 39.73 & 6.50 & 1.26 & 0.04 \\
\hline GeoB 3318-2 & $42^{\circ} 02.3^{\prime}$ & $75^{\circ} 19.3^{\prime}$ & $3207 \mathrm{~m}$ & 3.30 & 60.21 & 36.49 & 6.73 & 1.10 & 0.00 \\
\hline GeoB 3323-4 & $43^{\circ} 13.1^{\prime}$ & $75^{\circ} 57.0^{\prime}$ & $3697 \mathrm{~m}$ & 0.58 & 51.63 & 47.79 & 7.25 & 1.04 & -0.15 \\
\hline \multicolumn{10}{|l|}{ West of trench } \\
\hline GeoB 3388-2 & $25^{\circ} 13.2^{\prime}$ & $75^{\circ} 31.5^{\prime}$ & $3557 \mathrm{~m}$ & 7.88 & 30.94 & 61.18 & 7.48 & 0.95 & -0.17 \\
\hline GeoB 3383-1 & $28^{\circ} 15.0^{\prime}$ & $73^{\circ} 00.0^{\prime}$ & $4207 \mathrm{~m}$ & 7.78 & 45.04 & 47.18 & 7.13 & 1.28 & -0.20 \\
\hline GeoB 3372-4 & $29^{\circ} 56.3^{\prime}$ & $73^{\circ} 17.2^{\prime}$ & $4409 \mathrm{~m}$ & 1.26 & 45.20 & 53.34 & 7.37 & 1.09 & -0.19 \\
\hline GeoB 3308-3 & $33^{\circ} 07.9^{\prime}$ & $73^{\circ} 44.9^{\prime}$ & $3620 \mathrm{~m}$ & 1.12 & 38.64 & 60.24 & 7.52 & 1.01 & -0.19 \\
\hline GeoB 3347-1 & $35^{\circ} 15.0^{\prime}$ & $75^{\circ} 00.0^{\prime}$ & $4182 \mathrm{~m}$ & 0.81 & 37.52 & 61.68 & 7.74 & 0.84 & -0.20 \\
\hline GeoB 3327-6 & $43^{\circ} 14.4^{\prime}$ & $79^{\circ} 59.5^{\prime}$ & $3535 \mathrm{~m}$ & 0.62 & 45.04 & 54.33 & 7.79 & 0.73 & -0.32 \\
\hline GeoB 3326-1 & $43^{\circ} 14.1^{\prime}$ & $79^{\circ} 00.0^{\prime}$ & $3635 \mathrm{~m}$ & 0.94 & 43.79 & 55.28 & - & - & - \\
\hline GeoB 3328-1 & $43^{\circ} 14.0^{\prime}$ & $81^{\circ} 00.0^{\prime}$ & $3693 \mathrm{~m}$ & 0.42 & 43.30 & 56.28 & - & - & - \\
\hline
\end{tabular}

* GeoB = Geowissenschaften Bremen station. Samples recovered during R/V Sonne cruise SO 101-3; SO 102-1 and SO 102-2.

VG $=$ Vidal Gormaz station. Samples recovered during Thioploca cruise (march 1994).

a bulk sediment

b silt-fraction 
al. 1995). The deepest parts of the Peru-Chile trench are filled with northward-flowing Antarctic Bottom Water (Ingle et al. 1980).

\section{Continental geology and morphology}

North of $27.5^{\circ} \mathrm{S}$ Chile is divided from west to east into the Coastal Range, a longitudinal depression, and the Andes, which form the present volcanic arc (Scholl et al. 1970). The Coastal Range exhibits an abrupt morphological rise from sea level to elevations of 2000-2500 m. It consists primarily of Mesozoic intermediate calc-alkaline plutonites and subordinately of metamorphites and basaltic to andesitic volcanics (Zeil 1986; Thornburg and Kulm 1987b). The longitudinal depression is structurally a forearc alluvial basin (Thornburg and Kulm 1987b) filled with thick continental clastics and volcanoclastics which originate from the Andes (Zeil 1986). The volcanic arc itself is characterized by rhyolitic to andesitic ignimbrites (pre-Pliocene) overlain by Plio-Quaternary volcanoes. The volcanoes consist of andesitic rocks and tephra, and reach elevations of more than $6000 \mathrm{~m}$ (Zeil 1986).

From $27.5^{\circ} \mathrm{S}$ to $33^{\circ} \mathrm{S}$ Plio-Quaternary volcanism as well as alluvial forearc basins are absent (Fig. 1), due to a low angle of the subduction zone in this region (Jordan et al. 1983). The area is characterized by a constant increase in elevation from the coast up to the Andes. The geological features of the Coastal Range are comparable to those north of $27.5^{\circ} \mathrm{S}$. The Andes in this segment are characterized by more abundant plutonites, older sedimentary and volcanic rocks, as well as outcrops of the metamorphic basement (Zeil 1986). The elevation of the cordillera is high and reaches maximum values in latitudes around $33^{\circ} \mathrm{S}$ (up to $7000 \mathrm{~m}$ ).

South of $33^{\circ} \mathrm{S}$ morphological and geological features change abruptly (Lowrie and Hey 1981). As the dipping of the subduction zone reaches again higher values, Plio-Quaternary volcanism and forearc alluvial basins (the Chilean Central Valley; Fig. 1) are present again. The crestal elevation of the Coastal Range (average $1500 \mathrm{~m}$ ), and especially of the Andes, decreases significantly. The latter reveals a gradual average crestal elevation decrease from approximately $5000 \mathrm{~m}$ at $33^{\circ} \mathrm{S}$ to only $2000 \mathrm{~m}$ at $42^{\circ} \mathrm{S}$ (Scholl et al. 1970). The geology of the Coastal Range south of $33^{\circ} \mathrm{S}$ is marked by abundant, primarily low-grade metamorphic rocks (Zeil 1986). Especially north of approximately $38^{\circ} \mathrm{S}$ Paleozoic plutonites are also common (Ruiz and Corvalan 1968). The Chilean Central Valley is filled with up to 4000m-thick sequences of alluvial sediments (Zeil 1986). South of Puerto Montt $\left(41^{\circ} \mathrm{S}\right)$ the sea has ingressed into the Central Valley (Fig. 1). The basement of the Andes consists mainly of Mesozoic plutonites south of $41^{\circ} \mathrm{S}$. Between $33^{\circ} \mathrm{S}$ and $41^{\circ} \mathrm{S}$ more pre-Pliocene andesitic to rhyolitic volcanics and sediments crop out (Zeil 1986). The PlioQuaternary volcanics occurring throughout this Andean segment are more basic than in northern Chile (Thornburg and Kulm 1987b). Pleistocene glaciations reached the sea level south of $42^{\circ} \mathrm{S}$ and were restricted to crestal areas of the Andes further north (Paskoff 1977; Zeil 1986).

\section{Continental climate and hydrology}

The climatic features of Chile are summarized by Miller (1976) and reviewed by Heusser (1984). The climate of the study area can be categorized as follows (Fig. 1): north of $27^{\circ} \mathrm{S}$ the climate is hyper-arid with precipitation values of $<50 \mathrm{~mm} / \mathrm{a}$. Further south annual precipitation increases slightly due to rare passages of frontal systems of the Southern Westerlies in midwinter. From $31^{\circ} \mathrm{S}$ to $37^{\circ} \mathrm{S}$ the amount of winter rain grows significantly and the climate can be classified as semiarid Mediterranean. Summer dryness disappears south of Concepción $\left(37^{\circ} \mathrm{S}\right)$ and a humid temperate type of climate is developed with precipitation amounts of up to $2000 \mathrm{~mm} / \mathrm{a}$ in low elevations and even higher values in the Andes. Southern Chile (south of $42^{\circ} \mathrm{S}$ ) is characterized by humid, cool temperate conditions throughout the year with heavy precipitation varying depending on the exposure towards the very strong westerly winds in this region.

Depending mainly on the climatic conditions, the hydrology of the study area displays a similar latitudinal segmentation: north of $27.5^{\circ} \mathrm{S}$ transversal valleys in the Coastal Range, which reach the Pacific Coast, are nearly absent. From $27.5^{\circ} \mathrm{S}$ to $33^{\circ} \mathrm{S}$ rivers originating in the Andes generally cut through the Coastal Range but river discharge values are very low ( $<1 \mathrm{~km}^{3} / \mathrm{a}$; Milliman et al. 1995). Further south the density of river systems increases rapidly. Fluvial runoff is significantly higher and reaches up to $21 \mathrm{~km}^{3} / \mathrm{a}$ (Puelo River, ca. $41^{\circ} \mathrm{S}$; Milliman et al. 1995). Chilean rivers generally reveal steep river gradients and are short, rarely exceeding $200 \mathrm{~km}$ in length (Bio-Bio river: $380 \mathrm{~km}$; Milliman et al. 1995).

\section{Materials and methods}

The samples were recovered during the expeditions $\mathrm{R} / \mathrm{V}$ Sonne 101 and 102 (Hebbeln et al. 1995). Additional samples (courtesy H. Fossing, Max Planck Institute, Bremen, Germany) were recovered during the Thioploca cruise with R/V Vidal Gormaz in 1994 (Fossing et al. 1995). Samples were taken by a multicorer in order to obtain undisturbed surface samples of the uppermost centimeter of the sediment. The detailed location of the sampling stations is given in Table 1.

Forty-eight surface sediment samples were investigated concerning bulk mineralogy, bulk grain size, silt grain-size distribution, and clay mineralogy. For a few samples it was not possible to perform all analyses due to restricted availability of material (see Tables 1-3).

\section{Bulk mineralogy}

Bulk mineralogy was deduced from X-ray powder diffraction (XRD) analysis. A constant amount of $750 \mathrm{mg}$ of carbonate-free bulk sediment (sand-, silt-, and clay fraction; decarbonation by $10 \%$ acetic acid) was homogenized with $150 \mathrm{mg}$ of $\mathrm{Al}_{2} \mathrm{O}_{3}$ standard by carefully grinding with ace- 
tone in a mostar. The samples were then measured as cavity mounts using a Philips PW 1820 (Philips, Best, The Netherlands) diffractometer with $\mathrm{CoK} \alpha$ radiation. The spectrum from $3-100^{\circ} 2 \theta$ was measured with a stepwise velocity of $0.02^{\circ} 2 \theta / \mathrm{s}$.

The analysis of the mineral spectra of each sample was performed by manual evaluation of the main mineral peaks using the MacDiff software (R. Petschick, unpublished data). The used mineral peaks were: quartz (3.34 and $4.26 \AA$ ), plagioclase (3.19 $)$ ), K-feldspar (3.24 $\AA$ ), amphibole (8.4 $\AA$ ), clinopyroxene (3.00 $⿱$ ) , mica (10 ̊), and chlorite $(7 \AA)$. These mineral groups are clearly detectable in the diffractograms and are assumed to represent $100 \mathrm{wt} . \%$ of the carbonate and $\mathrm{C}_{\text {org }}$-free sediment. The calculation of weight percent of individual mineral phases was obtained by a calculation procedure which compares the measured intensity of each mineral to the maximum intensity of the pure phases (Emmermann and Lauterjung 1990) including the mass absorption of the total samples and individual minerals.

\section{Bulk grain size}

Prior to grain-size analysis the sediment was treated with $3.5 \%$ hydrogen peroxide for removal of organic matter and disaggregation and with $10 \%$ acetic acid in order to solve carbonate. Amorphous $\mathrm{SiO}_{2}$, including opal and volcanic glass, was not removed because XRD measurements and smear slide analyses revealed that only minor concentrations of amorphous $\mathrm{SiO}_{2}$ occur.

The sand fraction $(>63 \mu \mathrm{m})$ was removed by wet sieving. The silt- $(2-63 \mu \mathrm{m})$ and clay fraction $(<2 \mu \mathrm{m})$ were separated by Stokes'law settling using Atterberg tubes (Müller 1967). The settling procedure was repeated 9-12 times in order to separate the size fractions nearly completely. Coagulation of clay size particles was avoided by using a $1 \%$ sodium polyphosphate solution. Remaining sand and clay particles in the silt fraction were detected through the silt grain-size analysis.

\section{Silt grain-size distribution}

A detailed grain-size analysis of the silt fraction was performed using a Micromeritics SediGraph 5100. Micromeritics manufacturer location: Micromeritics Instrument Corporation, Norcross, U.S.A. Details about the operating procedures of the SediGraph are in Stein (1985), Jones et al. (1988), and Syvitszki (1991). The SediGraph analysis gives a high-resolution grain-size distribution in steps of 0.01 phi. In order to detect remaining sand and clay particles in the silt fraction, the analyses were performed in the 100 - to $0.63-\mu \mathrm{m}$ size range. Statistical grain-size parameters of the silt grain-size distributions were calculated by formulas from Folk and Ward (1957).
Clay mineralogy

The separated clay fraction was analyzed by X-ray diffractometer (XRD) measurements of oriented mounts following standard procedures described in detail by Petschick et al. (1996). The Mg-saturated clay fraction was examined for the four main clay mineral groups smectite, illite, kaolinite, and chlorite. Using a Philips PW 1820 (Philips, Best, The Netherlands) diffractometer with CoK $\alpha$ radiation $(40 \mathrm{kV}, 40 \mathrm{~mA})$ three XRD scans were run: firstly on the air-dry state (between 2 and $40^{\circ} 2 \theta, 0.02^{\circ}$ step size), secondly, after ethylene glycol solvation $\left(2-40^{\circ} 2 \theta, 0.02^{\circ}\right.$ step size), and finally, a slow scan between 28 and $30.5^{\circ} 2 \theta$ with steps of $0.005^{\circ} 2 \theta$ was obtained on the glycolated mounts in order to distinguish the 3.54/3.58 $\AA$ kaolinite/chlorite double peak.

The diffractograms were evaluated by the MacDiff software (R. Petschick, unpublished data). A semi-quantitative clay mineral analysis was performed by weighting integrated peak areas of the main basal reflections in the glycolated state using smectite $(17 \AA)$, illite $(10 \AA)$, and kaolinite/chlorite $(7 \AA)$. Relative proportions of kaolinite and chlorite were determined by the evaluation of the 3.54/3.58 $\AA$ double peak. The relative percentages of individual clay mineral groups were obtained using the empirically estimated weighting factors of Biscaye (1965). Additionally, Fe content and Fe distribution in the two layers of chlorite were calculated using the relative intensities of the chlorite 001 series (Moore and Reynolds 1989).

The crystallinity of illite and smectite was measured as the half height width (HHW) of the 10- $\AA$ illite peak and as the integral breadth (IB) of the glycolated $17-\AA$ smectite peak, respectively. The IB represents the breadth $\left(\Delta^{\circ} 2 \theta\right)$ of a rectangle of the same area and height as the peak.

\section{Results}

Bulk grain size

Surface sediments along the continental slope off Chile are mainly clayey silts to silty clays. Some nearshore stations of the northern part of the investigation area as well as the shelf samples of the $36^{\circ} \mathrm{S}$ transect contain more sand-sized material (sand to sandy mud/silt; Fig. 2; Table 1). Samples from areas west of the Peru-Chile trench are generally fine grained and can be classified as silty clays.

The bulk-sediment grain size reveals basically a fining trend with increasing water depth which is most pronounced in the $27^{\circ} \mathrm{S}$ and $33^{\circ} \mathrm{S}$ transects (Fig. 3A; Table 1). Exceptions are samples of the $36^{\circ} \mathrm{S}$ transect including very fine-grained (clayey silt to silty clay) nearshore and slope samples. Coarse-grained (sandy) sediments occur on the outer shelf and uppermost slope.

The bulk grain-size data exhibit also regional distribution patterns. The mean silt/clay ratios of the slope samples reach a minimum value at $35^{\circ} \mathrm{S}$. At this latitude silt/clay ratios of the pelagic samples reach a regional minimum as well (Fig. 3E). 


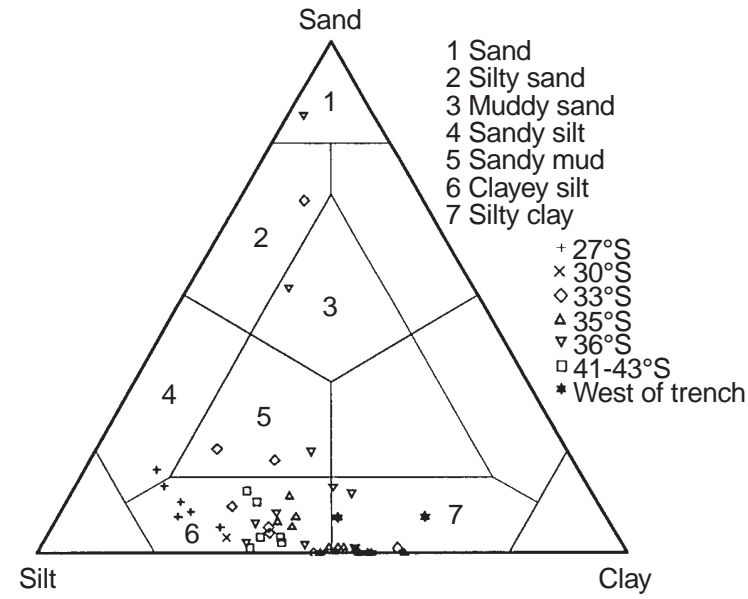

Fig. 2 Textural classification (after Shepard 1954) of carbonate-free bulk samples

\section{Silt grain-size distribution}

In the northernmost transect $\left(27^{\circ} \mathrm{S}\right.$; Figs. 3B-D, 4; Table 1) sediments are characterized by very homogenous silt grainsize distributions with median grain sizes in the coarse silt range. Silt fractions are very positively to positively skewed. Sorting values vary between 1.06 and 1.3 phi. The statistical grain-size parameters exhibit a slight trend towards finer grain sizes, poorer sorting, and less positive skewness with increasing water depth and offshore distance.

Silt grain-size parameters of surface samples of the $33^{\circ} \mathrm{S}$ transect (Figs. 3B-D, 4; Table 1) feature a conspicuous dependence on water depth with silt medians increasing from $<5$ phi (very coarse silt) nearshore to $>7$ phi (fine silt) near the Peru-Chile trench and skewness values ranging from 0.56 to -0.13 phi (very positively to negatively skewed) in the same area. Sorting values are mainly around 1.3 phi.

Surface samples at $35^{\circ} \mathrm{S}$ (Figs. 3B-D, 4; Table 1) reveal silt fractions which are significantly finer grained (medium to fine silt) than further north and negatively skewed. A minor offshore fining trend exists. The sorting values are variable. The silt medians of the shelf samples at $36^{\circ} \mathrm{S}$ are mainly in the medium silt grain-size range, positively skewed, and exhibit similar sorting values as in the $35^{\circ} \mathrm{S}$ transect (Figs. 3B-D, 4; Table 1). Further south, between 41 and $43^{\circ} \mathrm{S}$ (Figs. 3B-D, 4; Table 1), silt medians are predominantly in the bounds of medium silt and skewness values are variable but primarily slightly positive. Sorting ranges from 1.1 to 1.3 phi but does not correlate to increasing offshore distance. Surface samples from areas west of the Peru-Chile trench (Figs. 3B-D, 4; Table 1) are significantly finer grained and better sorted than the slope samples. Silt medians are in the fine silt range. A slight regional southward trend towards finer medians and more negative skewness is noted (Fig. 3F).

A regional comparison of the means of silt parameters of the slope transects (Fig. 3F) reveals coarse-grained and positively skewed silt fractions in the northern transect $\left(27^{\circ} \mathrm{S}\right)$ and a southward fining trend towards the $35^{\circ} \mathrm{S}$ transect. In this area the finest grained and most negatively skewed silt fractions occur. Median grain size and skewness values increase slightly again in the $41 / 43^{\circ} \mathrm{S}$ transect. Sorting values do not display significant regional distribution patterns along the Chilean continental margin.

\section{Bulk mineralogy}

Bulk mineralogical data exhibit mainly regional variations and only subordinate local changes with increasing water depth and offshore distance. Samples from areas west of the Peru-Chile trench reveal very similar regional distribution patterns compared with the slope sediments (Fig. 5E, F).

Feldspar is the dominant mineral in all transects and also in the sediments west of the Peru-Chile trench. Feldspars are predominantly plagioclases. The plagioclase content ranges from 38 to 53 wt.\% with highest mean values between $33^{\circ} \mathrm{S}$ and $36^{\circ} \mathrm{S}$ (Fig. 5E). The $35^{\circ} \mathrm{S}$ transect is characterized by very constant plagioclase contents (Fig. $5 B)$. K-feldspars occur only in subordinate amounts with maximum values at $27^{\circ} \mathrm{S}$ (Table 2 ).

The second most abundant phase, quartz (Fig. 5A), reaches maximum values in the $27^{\circ} \mathrm{S}$ transect (23-40 wt.\%) with a relatively high variability within the transect. Further south the mean amount of quartz gradually decreases to values of less than $20 \mathrm{wt} . \%$ in the $41^{\circ} \mathrm{S}$ to $43^{\circ} \mathrm{S}$ transect (Fig. $5 \mathrm{E})$. Quartz abundances are more constant within the southern transects especially in the $35^{\circ} \mathrm{S}$ area (Fig. 5A).

The third most abundant minerals are amphiboles in the north and pyroxenes in the southern part of the study area, respectively, with a generally reverse distribution pattern (Fig. 5F). While amphiboles range from up to $17 \mathrm{wt} . \%$ in the north, $2-7 \mathrm{wt} . \%$ in the $35^{\circ} \mathrm{S}$ to $36^{\circ} \mathrm{S}$ area, and $5-10$ wt.\% in the southernmost transect (Fig. 5C), the respective values for pyroxene are 7-12 wt.\%, 12-15 wt.\%, and up to 19 wt.\% (Fig. 5D). Amphibole contents reveal a comparatively high variability especially within the northernmost transects (Fig. 5C). Pyroxene amounts are relatively constant within each transect (Fig. 5D).

Mica contents also display a regional pattern (Fig. 5F; Table 2). Highest mean values occur in the $27^{\circ} \mathrm{S}$ and $30^{\circ} \mathrm{S}$ transects (3-6 wt.\%) and in the southernmost $41^{\circ} \mathrm{S}$ to $43^{\circ} \mathrm{S}$ transect (5-8 wt.\%). Chlorite occurs in minor amounts in the bulk fraction and is slightly more abundant in the central part of the study area, especially in the $35^{\circ} \mathrm{S}$ and $36^{\circ} \mathrm{S}$ transects (Table 2).

\section{Clay mineralogy}

Distribution patterns of the relative abundance of the four main clay mineral groups smectite, illite, chlorite, and kaolinite, as well as crystallinity and chemistry parameters of selected clay minerals, reveal significant regional patterns but also local variations within the transects.

Clay mineral assemblages of the $27^{\circ} \mathrm{S}$ transect are dominated by well-crystallized smectite ranging from 56 to 

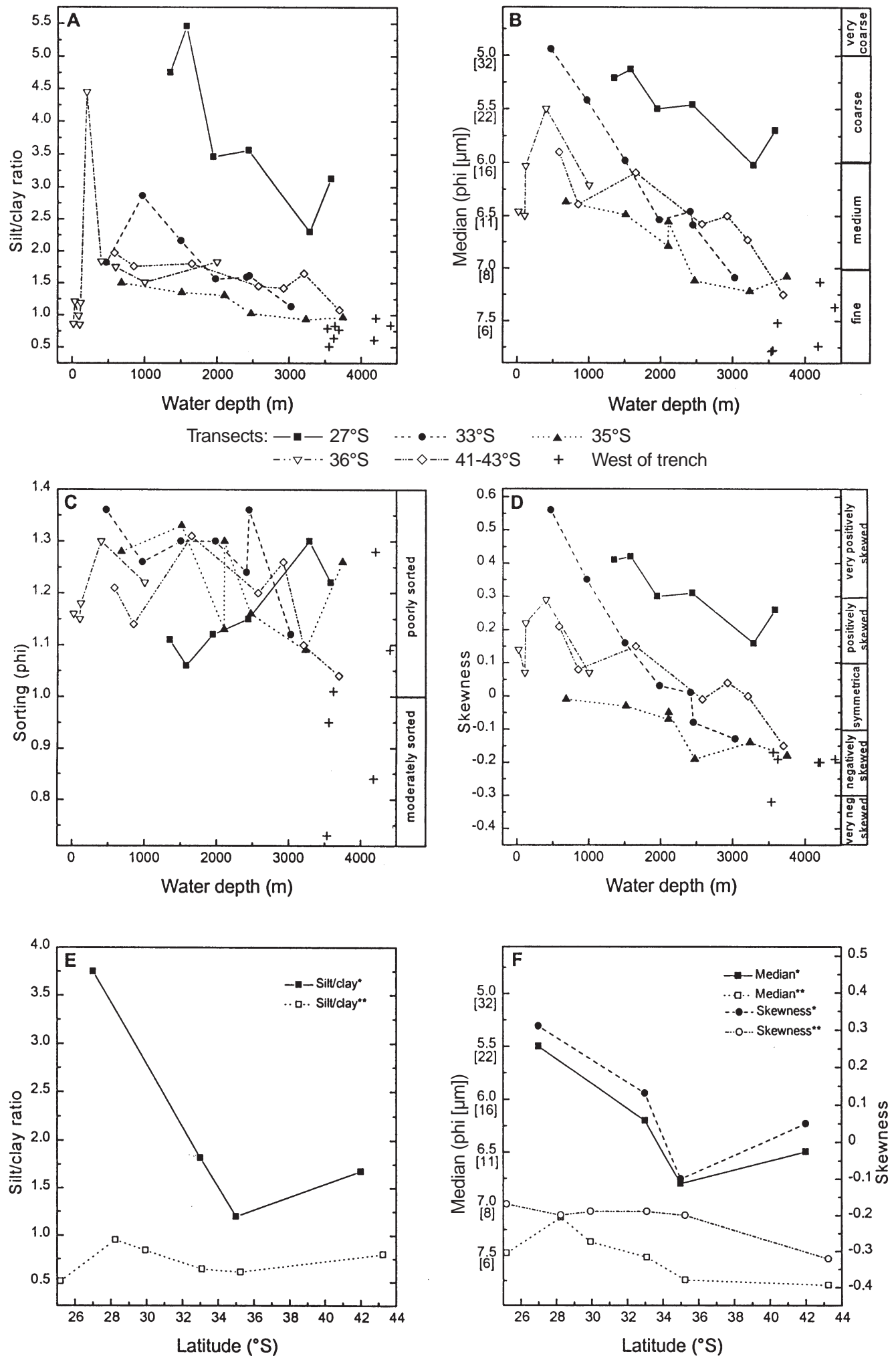

* Mean of each transect

** Samples west of trench

Fig. 3A-F Grain-size data of surface samples of each transect and of samples from areas west of the Peru-Chile trench. Data are plotted A-D vs water depth and $\mathbf{E}, \mathbf{F}$ as mean values vs latitude. A Silt/clay ratio of the carbonate-free bulk sediment as a representative parameter for the bulk grain size. B-D Statistical grain-size parameters (me-

dian, sorting, and skewness) of the carbonate-free silt fraction. Medians are classified after Friedman and Sanders (1978), sorting and skewness values after Folk and Ward (1957). E, F Mean silt/clay ratio, median, and skewness of each transect compared with data of samples from west of the trench 
Fig. 4 Silt grain-size distributions of carbonate-free surface sediments of each transect. Water depth of each sample is indicated
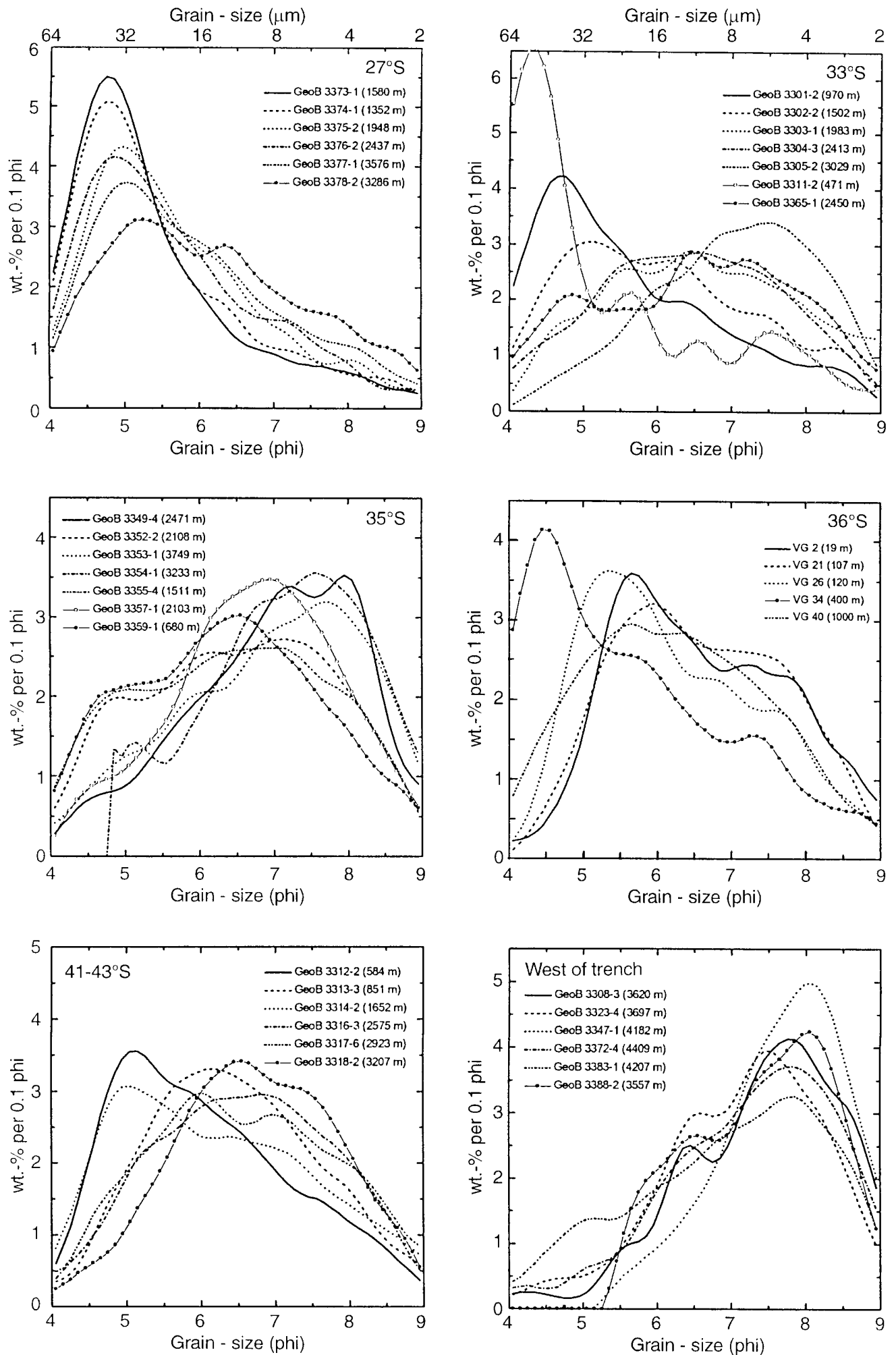
Fig. 5A-F Bulk mineralogical data of surface samples of each transect and of samples from areas west of the Peru-Chile trench. Data are plotted A-D vs water depth and $\mathbf{E}, \mathbf{F}$ as mean values vs latitude. A Quartz content; B feldspar content; C amphibole content; D pyroxene content; E mean quartz and feldspar contents of each transect compared with data of samples from west of the trench. F Mean amphibole, pyroxene, and mica contents of each transect compared with data of samples from west of the trench
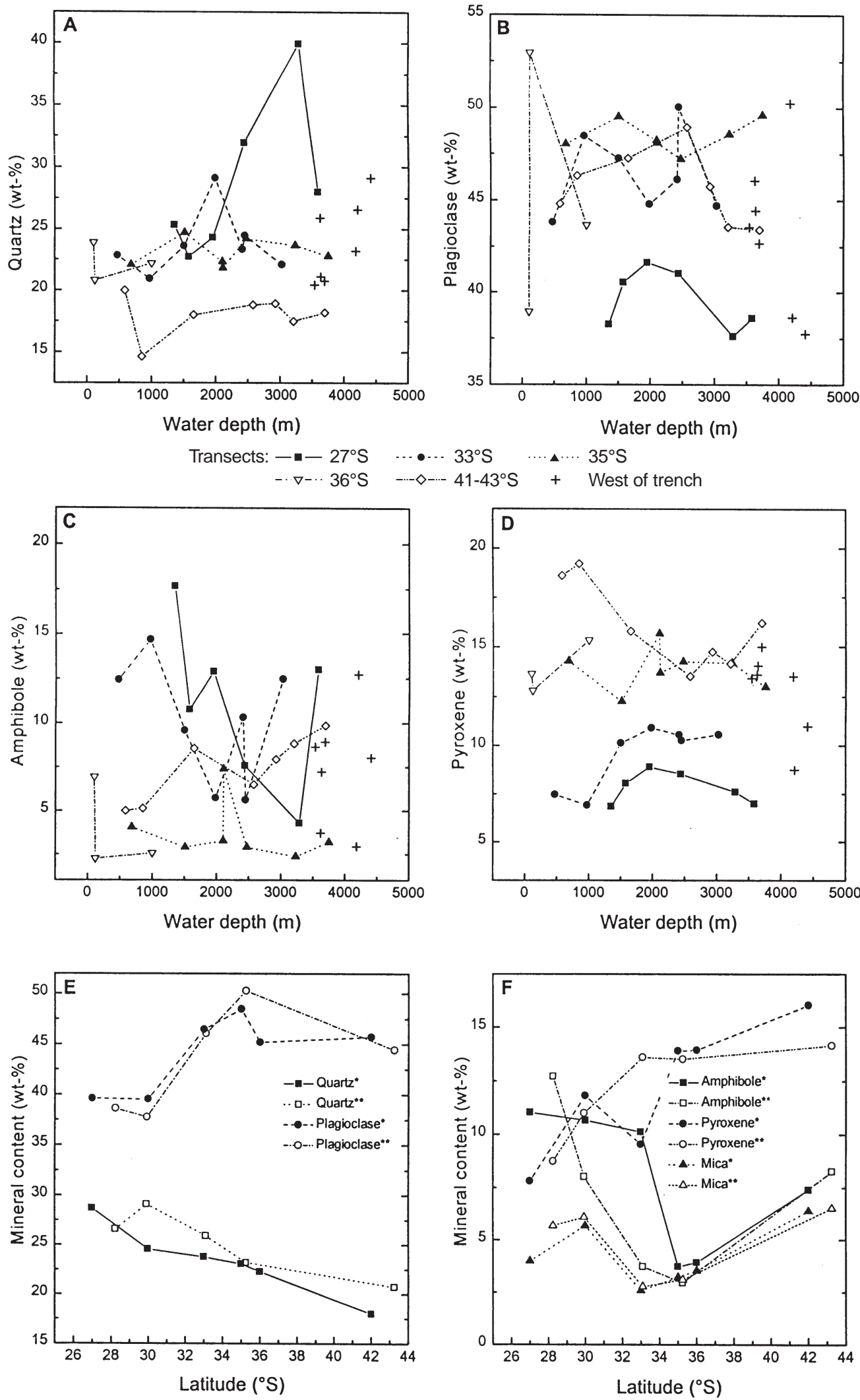

* Mean of each transect

${ }^{* *}$ Samples west of trench 
Table 2 Bulk mineralogical data of surface samples from the Chilean continental margin between $25^{\circ} \mathrm{S}$ and $43^{\circ} \mathrm{S}$. For location and water depths of the sample stations see Table 1

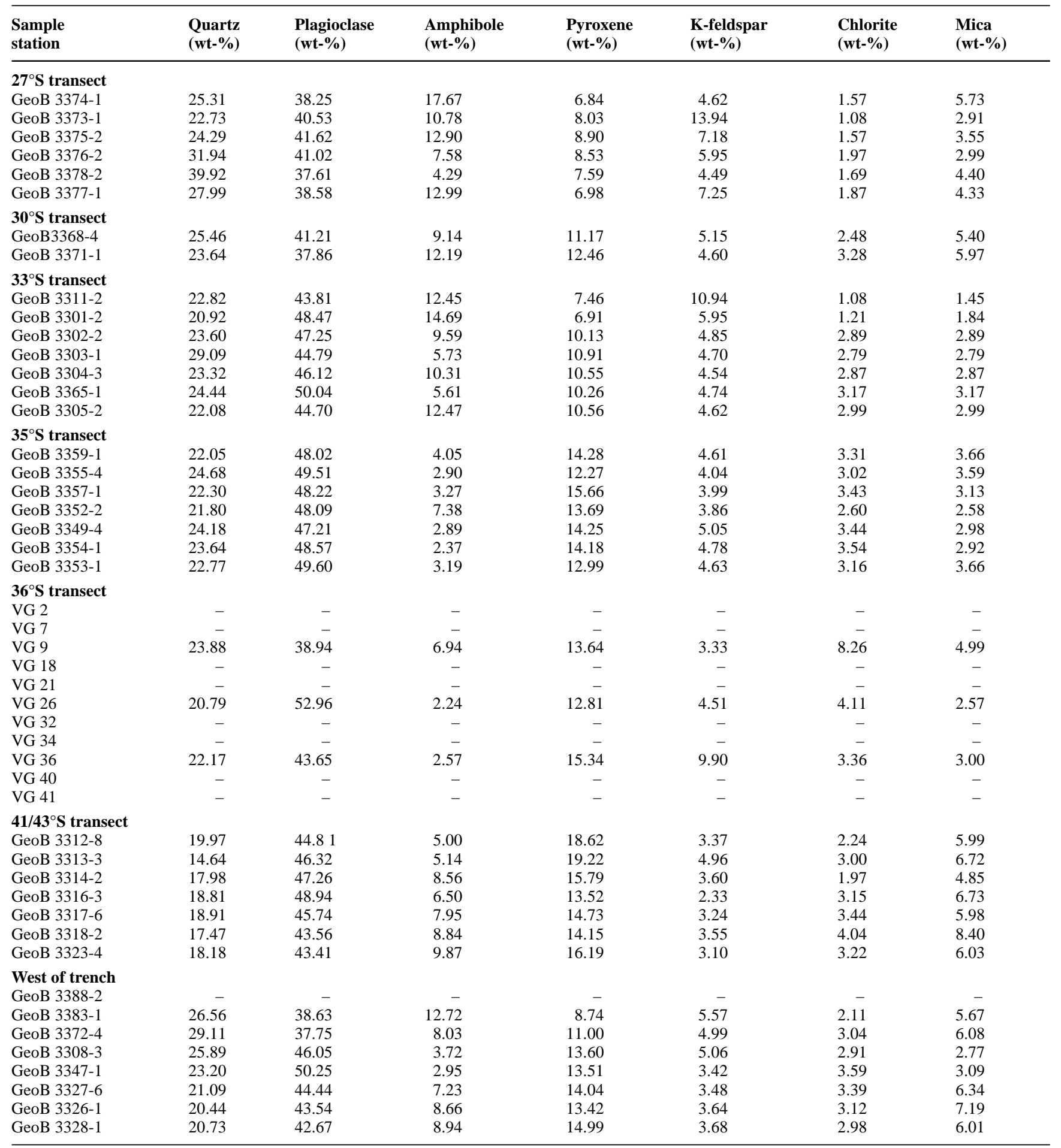

66\% (Fig. 6A) with crystallinities (IB) between 1.4 and 1.6 $\Delta^{\circ} 2 \theta$ (Table 3). The secondmost abundant clay mineral is illite (20-26\%; Fig. 6B). Illite crystallinities are comparatively well and vary around $0.4 \Delta^{\circ} 2 \theta$ (Fig. 6D). Chlorite amounts are low (11-14\%; Fig. 6C) as well as the Fe content of this clay mineral (Table 3). Kaolinite contents are very minor reaching only 3-5\% (Table 3 ). Clay mineralogical parameters show no evolution with water depth or offshore distance in the $27^{\circ} \mathrm{S}$ transect.

The $33^{\circ} \mathrm{S}$ transect is characterized by a stronger water depth and offshore distance controlled clay mineralogy. Smectite contents are generally lower (44-57\%) than fur- 
Fig. 6 Clay mineralogical data of surface samples of each transect and of samples from areas west of the Peru-Chile trench. Data are plotted A-D vs water depth and $\mathbf{E}, \mathbf{F}$ as mean values vs latitude. A-C Relative contents of the three main clay mineral groups (smectite, illite, and chlorite). D Illite crystallinity calculated as HHW (in $\Delta^{\circ} 2 \theta$ ). $\mathbf{E}$ Mean clay mineral contents of each transect compared with data of samples from west of the trench. F Mean illite crystallinity of each transect compared with data of samples from west of the trench
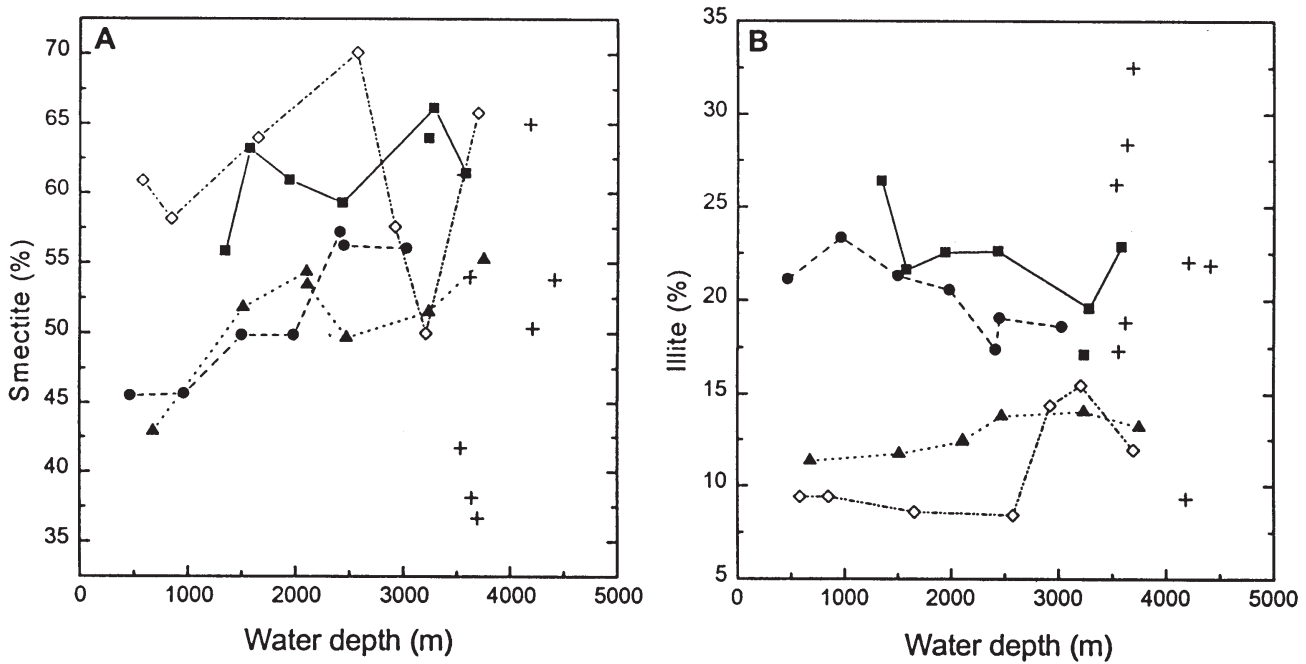

Transects: $--27^{\circ} S \quad \cdots \bullet \cdots 33^{\circ} S \quad \cdots \cdots 35^{\circ} S$
$-\cdots-\cdots-41-43^{\circ} S+$ West of trench
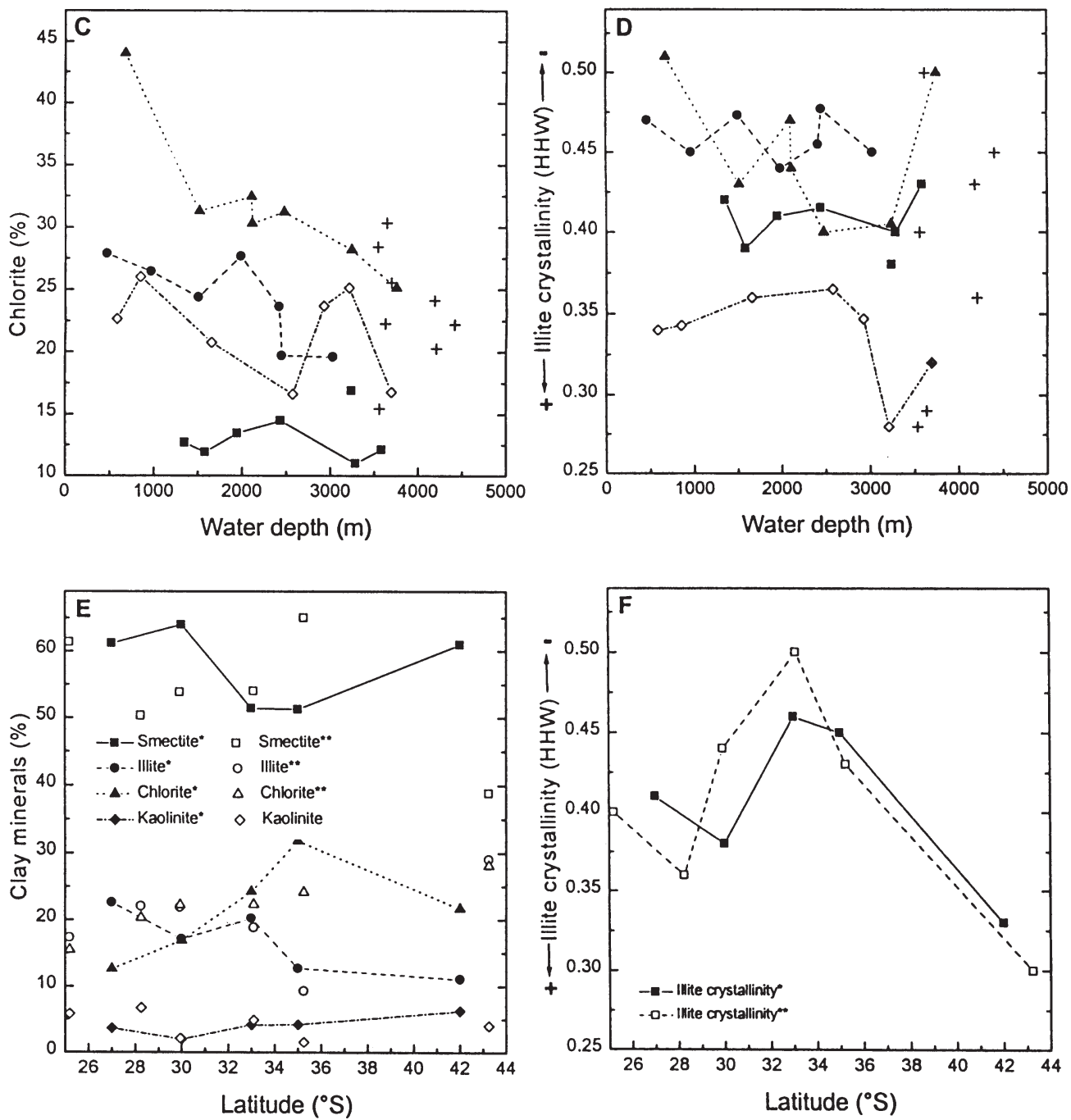

* Mean of each transect

** Samples west of trench 
Table 3 Clay mineralogical data of surface samples from the Chilean continental margin between $25^{\circ} \mathrm{S}$ and $43^{\circ} \mathrm{S}$. For location and water depths of the samples stations see Table 1

\begin{tabular}{|c|c|c|c|c|c|c|c|}
\hline $\begin{array}{l}\text { Sample } \\
\text { station }\end{array}$ & $\begin{array}{l}\text { Smectite } \\
(\%)\end{array}$ & $\begin{array}{l}\text { Illite } \\
(\%)\end{array}$ & $\begin{array}{l}\text { Chlorite } \\
(\%)\end{array}$ & $\begin{array}{l}\text { Kaolinite } \\
(\%)\end{array}$ & $\begin{array}{l}\text { Illite HHW' } \\
\left(\Delta^{\circ} 2 \theta\right)\end{array}$ & $\begin{array}{l}\text { Smectite IB }{ }^{\mathbf{c}} \\
\left(\Delta^{\circ} 2 \theta\right)\end{array}$ & $\begin{array}{l}\text { Chlorite } \\
\left(\mathbf{Y}^{\mathbf{d}}\right)\end{array}$ \\
\hline \multicolumn{8}{|l|}{$27^{\circ} \mathrm{S}$ transect } \\
\hline GeoB 3374-1 & 55.82 & 26.39 & 12.69 & 5.10 & 0.42 & 1.46 & 1.20 \\
\hline GeoB 3373-1 & 63.20 & 21.62 & 11.91 & 3.27 & 0.39 & 1.49 & 1.13 \\
\hline GeoB 3375-2 & 60.95 & 22.54 & 13.46 & 3.06 & 0.41 & 1.39 & 1.43 \\
\hline GeoB 3376-2 & 59.29 & 22.60 & 14.48 & 3.63 & 0.41 & 1.36 & 1.10 \\
\hline GeoB 3378-2 & 66.15 & 19.57 & 11.00 & 3.28 & 0.40 & 1.49 & 1.01 \\
\hline GeoB 3377-1 & 61.45 & 22.85 & 12.14 & 3.55 & 0.43 & 1.54 & 0.97 \\
\hline \multicolumn{8}{|l|}{$30^{\circ} \mathrm{S}$ transect } \\
\hline GeoB 3368-4 & 63.97 & 17.09 & 16.91 & 2.02 & 0.38 & 1.59 & 1.32 \\
\hline GeoB 3371-1 & - & - & - & - & - & - & - \\
\hline \multicolumn{8}{|l|}{$3^{\circ} \mathrm{S}$ transect } \\
\hline GeoB 3311-2 & 45.50 & 21.10 & 27.89 & 5.51 & 0.47 & 1.48 & 1.98 \\
\hline GeoB 3301-2 & 45.65 & 23.34 & 26.45 & 4.57 & 0.45 & 1.32 & 1.59 \\
\hline GeoB 3302-2 & 49.83 & 21.30 & 24.38 & 4.49 & 0.47 & 1.33 & 1.47 \\
\hline GeoB 3303-1 & 49.83 & 20.53 & 27.67 & 1.97 & 0.44 & 1.32 & 1.42 \\
\hline GeoB 3304-3 & 57.17 & 17.38 & 23.63 & 1.82 & 0.45 & 1.60 & 1.61 \\
\hline GeoB 3365-1 & 56.22 & 19.05 & 19.69 & 5.04 & 0.47 & 1.45 & 1.27 \\
\hline GeoB 3305-2 & 56.03 & 18.59 & 19.61 & 5.77 & 0.45 & 1.40 & 1.19 \\
\hline \multicolumn{8}{|l|}{$35^{\circ} \mathrm{S}$ transect } \\
\hline GeoB 3359-1 & 42.91 & 11.34 & 43.99 & 1.77 & 0.51 & 1.52 & 3.53 \\
\hline GeoB 3355-4 & 51.81 & 11.72 & 31.30 & 5.17 & 0.43 & 1.53 & 2.71 \\
\hline GeoB 3357-1 & 54.34 & 12.39 & 32.46 & 0.81 & 0.47 & 1.50 & 3.03 \\
\hline GeoB 3352-2 & 53.41 & 12.46 & 30.29 & 3.84 & 0.44 & 1.44 & 2.08 \\
\hline GeoB 3349-4 & 49.65 & 13.79 & 31.23 & 5.33 & 0.40 & 1.50 & 2.38 \\
\hline GeoB 3354-1 & 51.51 & 14.02 & 28.19 & 6.28 & 0.40 & 1.45 & 2.04 \\
\hline GeoB 3353-1 & 55.23 & 13.20 & 25.11 & 6.46 & 0.50 & 1.49 & 2.21 \\
\hline \multicolumn{8}{|l|}{$36^{\circ} \mathrm{S}$ transect } \\
\hline VG 2 & 0.60 & 19.98 & $79.43^{\mathrm{a}}$ & - & 0.61 & - & - \\
\hline VG 7 & 0.88 & 18.28 & $80.84^{\mathrm{a}}$ & - & 0.45 & - & - \\
\hline VG 9 & - & - & - & - & & & \\
\hline VG 18 & 2.64 & 17.23 & $80.13^{a}$ & - & 0.57 & - & - \\
\hline VG 21 & 1.61 & 15.35 & $83.04^{\mathrm{a}}$ & - & 0.52 & - & 5.60 \\
\hline VG 26 & 9.11 & 13.12 & $77.77^{\mathrm{a}}$ & - & 0.54 & - & 5.70 \\
\hline VG 32 & - & - & - & - & - & - & 3.80 \\
\hline VG 34 & 12.30 & 14.20 & $73.50^{\mathrm{a}}$ & - & 0.46 & - & 3.50 \\
\hline VG 36 & 14.72 & 12.54 & $72.74^{\mathrm{a}}$ & - & 0.50 & - & 3.65 \\
\hline VG 40 & 17.28 & 13.36 & $69.36^{\mathrm{a}}$ & - & 0.43 & - & 3.10 \\
\hline VG 41 & 12.21 & 15.71 & $72.08^{\mathrm{a}}$ & - & 0.46 & - & 3.00 \\
\hline \multicolumn{8}{|c|}{$41 / 43^{\circ} \mathrm{S}$ transect } \\
\hline GeoB 3312-8 & 60.92 & 9.40 & 22.66 & 7.02 & 0.34 & 1.63 & 1.28 \\
\hline GeoB 3313-3 & 58.16 & 9.42 & 26.01 & 6.41 & 0.34 & 1.65 & 1.85 \\
\hline GeoB 3314-2 & 64.00 & 8.59 & 20.77 & 6.64 & 0.36 & 1.72 & 1.71 \\
\hline GeoB 3316-3 & 70.09 & 8.43 & 16.63 & 4.85 & 0.36 & 1.75 & 1.73 \\
\hline GeoB 3317-6 & 57.28 & 14.36 & 23.69 & 4.37 & 0.34 & 1.61 & 1.36 \\
\hline GeoB 3318-2 & 49.99 & 15.47 & 25.14 & 9.40 & 0.28 & 1.49 & 1.07 \\
\hline GeoB 3323-4 & 65.79 & 11.94 & 16.78 & 5.50 & 0.32 & 1.71 & 1.23 \\
\hline \multicolumn{8}{|c|}{ West of trench } \\
\hline GeoB 3388-2 & 61.35 & 17.31 & 15.45 & 5.89 & 0.40 & 1.69 & 0.75 \\
\hline GeoB 3383-1 & 50.34 & 22.04 & 20.28 & 6.80 & 0.36 & 1.39 & 1.07 \\
\hline GeoB 3372-4 & 53.81 & 21.87 & 22.21 & 2.12 & 0.44 & 1.51 & 1.38 \\
\hline GeoB 3308-3 & 53.98 & 18.81 & 22.28 & 4.93 & 0.50 & 1.41 & 1.45 \\
\hline GeoB 3347-1 & 64.99 & 9.30 & 24.13 & 1.58 & 0.43 & 1.52 & 2.00 \\
\hline GeoB 3327-6 & 41.70 & 26.21 & 28.42 & 3.67 & 0.28 & 1.42 & 0.98 \\
\hline GeoB 3326-1 & 38.13 & 28.38 & 30.34 & 3.14 & 0.29 & 1.35 & 0.91 \\
\hline GeoB 3328-1 & 36.67 & 32.51 & 25.54 & 5.29 & 0.32 & 1.46 & 0.69 \\
\hline
\end{tabular}

ther north and reveal an increasing trend offshore (Fig. 6A). Correspondingly, illite and chlorite tend to increase towards the continent with values of $17-23 \%$ and $20-28 \%$, respectively (Fig. 6B, C). Additionally, minor amounts of kaolinite $(2-6 \%)$ are present (Table 3$)$. Illite crystallinities are sig- nificantly poorer than further north $\left(0.44-0.47 \Delta^{\circ} 2 \theta\right.$; Fig. 6D), whereas smectite crystallinities are comparable to the $27^{\circ} \mathrm{S}$ tansects (Table 3 ).

At $35^{\circ} \mathrm{S}$ significantly lower smectite and illite contents, but higher chlorite amounts, occur (Fig. 6A-C). The re- 
spective values are predominantly in the range of $50-55 \%$ for smectite, $11-14 \%$ for illite, and $25-44 \%$ for chlorite. Kaolinite contents are again only minor (1-6\%; Table 3 ). Smectite and chlorite contents show a reverse evolution with increasing water depth where chlorite amounts diminish. Illites reveal comparatively poor crystallinities (0.4-0.51 $\Delta^{\circ} 2 \theta$; Fig. 6D). Smectite IB values are medium and vary around $1.5 \Delta^{\circ} 2 \theta$ (Table 3 ). The Fe content of chlorite is significantly higher than in the northern transects (Table 3 ).

Clay mineral assemblages of the $36^{\circ} \mathrm{S}$ area (Table 2) are dominated by Fe-rich chlorite with extremely high abundances mainly in the range of $70-80 \%$. Illite contents vary from 13 to $20 \%$ and are comparatively poorly crystallized. The relative amount of smectite is very small remaining below $10 \%$ on the shelf and reaching up to $17 \%$ on the upper continental slope. Due to extremely high abundances of chlorite, the kaolinite content could not be determined.

The southernmost transect $\left(41^{\circ} \mathrm{S}\right.$ to $\left.43^{\circ} \mathrm{S}\right)$ exhibits generally high smectite contents (mostly 57-70\%; Fig. 6A) with poor crystallinities (IB approximately $1.7 \Delta^{\circ} 2 \theta$; Table $3)$. Illite amounts are very low (8-15\%; Fig. 6B) and are very well crystallized $\left(0.28-0.36 \Delta^{\circ} 2 \theta\right.$; Fig. $\left.6 \mathrm{D}\right)$. Chlorite contents are medium, ranging from 17 to $26 \%$, and show comparatively low Fe contents (Table 3 ). Additionally, minor amounts of kaolinite (4-9\%) are present (Table 3). Neither of the clay mineral parameters display any waterdepth-related evolution in this transect.

The clay mineral contents of samples recovered west of the Peru-Chile trench are generally in the range of those of neighboring slope samples (Fig. 6A-C, E). Exceptions are the southernmost more offshore samples (Table 3). They contain significantly less smectite (ca. $40 \%$ ), which is well crystallized (IB ca. $1.4 \Delta^{\circ} 2 \theta$; Table 3 ). Illite and Chlorite occur in approximately equal amounts of approximately $30 \%$ in these samples.

Regional patterns of clay mineralogical parameters become clearer by looking at the mean values of individual clay mineral parameters in each transect (Fig. 6E-F). The $36^{\circ} \mathrm{S}$ transect is not considered here. Mean smectite contents reveal a regional minimum in the $33^{\circ} \mathrm{S}$ to $35^{\circ} \mathrm{S}$ area, where chlorite amounts reach maximum values. Illite contents generally decrease from north to south throughout the study area. Kaolinite contents are minor and exhibit no regional distribution pattern. The illite crystallinity shows a significant regional pattern indicating poorest crystallinities in the $33^{\circ} \mathrm{S}$ and $35^{\circ} \mathrm{S}$ transects, which is also visible in samples recovered west of the Peru-Chile trench (Fig. 6F).

\section{Discussion}

Grain-size, bulk-, and clay mineralogical data are discussed separately for each transect. Sedimentological parameters and controlling factors for the slope tansects are summarized in Fig. 7.

\section{Grain-size distributions}

High silt/clay ratios and coarse silt medians in surface sediments of the northernmost transect $\left(27^{\circ} \mathrm{S}\right)$ are explained by the arid continental climate, predominantly plutonic source-rock composition, and prevailing eolian sediment input. An influence of turbiditic processes and bottom currents on our textural data is excluded because of the relatively homogeneous distribution pattern of the measured grain-size parameters throughout the slope from water depths of 1300-3600 m. Firstly, physical weathering, which predominates in arid climates, provides generally coarse-grained source material. Several authors (e.g., Summerhayes et al. 1976; Krissek et al. 1980) have found that the amount of sediment derived from a landmass decreases but its grain size increases as the climate becomes more arid. Secondly, plutonites are dominant in the Coastal Range in the $27^{\circ} \mathrm{S}$ to $30^{\circ} \mathrm{S}$ area and exhibit a coarser-grained primary texture than volcanics. Thirdly, silt grain-size parameter and the homogeneity of the silt grain-size distributions of the $27^{\circ} \mathrm{S}$ transect (Fig. 4) suggest notable eolian sediment supply. Comparable grain-size distributions have been found in eolian shelf and slope sediments off northern Africa (e.g., Sarnthein et al. 1984).

The hinterland of the $33^{\circ} \mathrm{S}$ transect is still characterized by relatively coarse-grained source material due to prevailing mechanical weathering under a semiarid climate and high morphological gradients. But as winter rain increases, sediment is mainly supplied by rivers. The strong offshore fining trend of the bulk- and silt grain size at short distances indicates a strong energy gradient as occurs off river mouths (e.g., Reading and Collinson 1996). Eolian sediment input is less important. The fluvially supplied material is probably mainly deposited by hemipelagic processes, as turbidity currents are channelized off central Chile $\left(33-38^{\circ} \mathrm{S}\right)$ and are restricted to submarine canyon and fan systems (Thornburg and Kulm 1987a), which have not been sampled.

In comparison with the $33^{\circ} \mathrm{S}$ transect, the significantly finer grained bulk- and silt grain sizes at $35^{\circ} \mathrm{S}$ are explained by finer-grained source material due to abundant volcanic source rocks (see Bulk mineralogy) and to increasing precipitation which promotes chemical weathering. Moreover, morphological gradients in the hinterland are less pronounced than further north, and some coarser grained terrigenous material might be trapped in both the Chilean Longitudinal Valley and on the shelf which becomes wider in this area.

The shelf samples of the $36^{\circ} \mathrm{S}$ region reflect a more variable environment due to the complexity of shelf dynamics. Fine-grained shelf sediments occur in very nearshore areas within the Bay of Concepción indicating local calm-water conditions. Sandy sediments on the outer shelf and uppermost slope probably result from winnowing by normal bottom currents (Stow 1986) and/or resedimentation processes.

Mean grain sizes in the southernmost transect $\left(41^{\circ} \mathrm{S}\right.$ to $43^{\circ} \mathrm{S}$ ) are slightly coarser than at $35^{\circ} \mathrm{S}$, due possibly to coarser-grained source rocks and less chemical weathering 


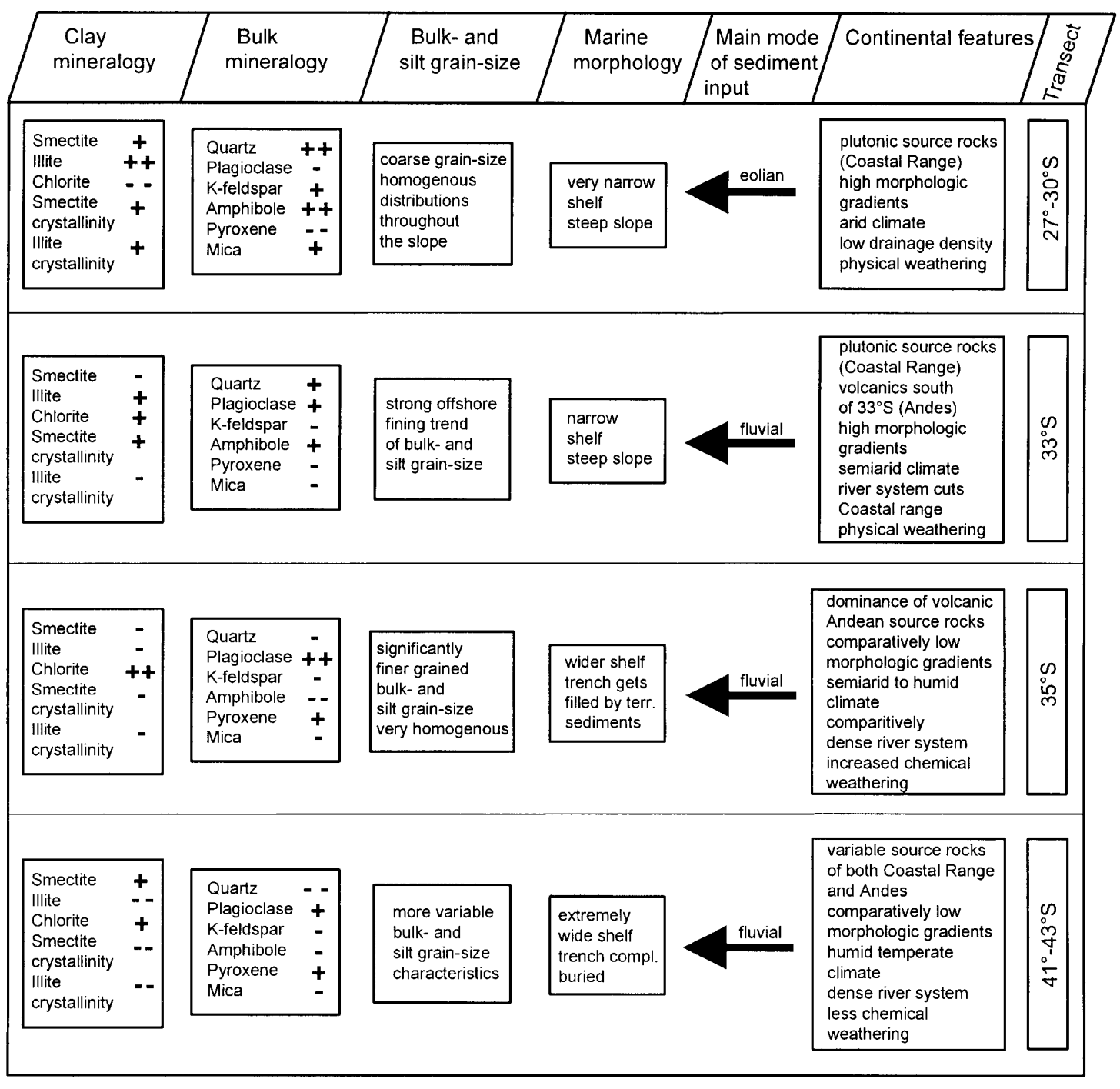

Fig. 7 Summary of sedimentological parameters of the slope transects and factors controlling the regional pattern of each transect along the Chilean continental margin

in the hinterland (as indicated by bulk and clay mineralogical data; see below). On the other hand, the marine sedimentary environment in this area is characterized by very high sediment input and resedimentation processes of fluvial material on the shelf and upper slope (Thornburg and Kulm 1987a); thus, especially surface samples with more positively skewed, coarser grain-size distributions (Fig. 4) may represent distal turbidites.

\section{Bulk mineralogy}

Short transport distances, high morphological gradients, and limited chemical weathering preserved the original source-rock signal in the analyzed surface samples. Generally low quartz contents, the dominance of plagioclase, and high amounts of pyroxenes and amphiboles emphasizes the low maturity of the sediments (Fig. 5).
Compared with the southern transects high quartz, amphibole, K-feldspar, and mica contents, and less plagioclase and pyroxenes in surface sediments of the northernmost transect, are explained by the dominance of plutonites in the Coastal Range with lesser amounts of metamorphites and basaltic to andesitic volcanics. Due to the few rivers cutting through the Coastal Range, the influence of source rocks from the Andes can only be minor.

Towards the $33^{\circ} \mathrm{S}$ transect quartz, K-feldspar, and mica contents decrease, and plagioclase and pryroxene amounts increase, while the amphibole content remains roughly constant. While the source-rock composition in the Coastal Range does not change significantly, the mineralogical modifications may be due to an increasing contribution of Andean source rocks towards the south supplied from areas east of the Coastal Range by rivers. Trench sands of the $33^{\circ} \mathrm{S}$ area are attributed to Andean source rocks, especially to Quaternary volcanics at the northern limit of active volcanism of the South Chile province $\left(33^{\circ} \mathrm{S}\right.$; Fig. 1; Thornburg and Kulm 1987b).

A possible explanation for the high variability of the bulk mineralogical composition within the transects of the 
$27^{\circ} \mathrm{S}$ to $33^{\circ} \mathrm{S}$ region (Fig. 5) is the limited onshore drainage areas. Due to the arid to semiarid climate with only episodic flooding events, the source-rock signal of individual surface samples might reflect variable local geological conditions in the respective drainage basins.

The most immature bulk mineralogical assemblage of the study area occurs in the $35^{\circ} \mathrm{S}$ to $36^{\circ} \mathrm{S}$ area (i.e., very high plagioclase and pyroxene contents, the lowest amphibole amounts, and comparatively low quartz contents). This is in agreement with findings of Baba (1986) for river samples and Thornburg and Kulm (1987b) for trench sands at similar latitudes. The very immature character of the sediments is in contrast to maximum chemical weathering intensities expected by the climatic conditions in this area, i.e., a combination of high rainfall and temperature. However, high morphological gradients at the active Chilean continental margin and seasonal precipitation (i.e., maximum rainfall in winter coincides with minimum temperatures) might explain reduced chemical weathering rates and thus unaltered bulk-mineral assemblages. Baba (1986) suggested that the high rainfall induces a rapid rock erosion which offsets the increased weathering intensity. Source rocks in the $33^{\circ} \mathrm{S}$ to $38^{\circ} \mathrm{S}$ segment include abundant metamorphites in the Coastal Range and dominant volcanics (basalts to basaltic andesites) in the Andes. Our bulk mineralogical data indicate a dominance of debris from Andean source rocks transported by the high discharging river system. The mineral assemblage of the $35^{\circ} \mathrm{S}$ transect reveals the lowest variability within the continental slope transects of the study area (Fig. 5) reflecting extended drainage areas and the dominance of the Andean source rocks. Thornburg and Kulm (1987b) also noted the singularity of provenance for trench sands in this area due to the overwhelming contribution of high erodible volcanics of the Andes.

In the southernmost part of the study area $\left(41^{\circ} \mathrm{S}\right.$ to $\left.43^{\circ} \mathrm{S}\right)$ the heterogeneity of the bulk mineralogy within the transect increases. While feldspar and quartz contents are comparatively low, amphibole and mica amounts reach their maximum values within the study area. The sediments are probably derived from various source rocks including metamorphites of the Coastal Range and volcanics and plutonites of the Andes. Due to the extreme width of the shelf, including the sea-covered forearc basin and the dissection of the Coastal Range to islands, the provenance of surface samples cannot be related directly to single drainage basins. The variability of our data within the slope results from varying source-rock contributions and likely shelf dynamics, as well as resedimentation processes on the slope as indicated by the grain-size data. Thornburg and Kulm (1987b) also observed a mixed igneous and metamorphic provenance for trench sediments around $42^{\circ} \mathrm{S}$ and explained the diversity of the mineralogical assemblage by mixing processes in fluvial and shallow-marine environments.

\section{Clay mineralogy}

The clay mineral assemblage along the Chilean continental margin is generally dominated by smectite followed by illite in the northernmost part of the study area $\left(27^{\circ} \mathrm{S}\right.$ to $30^{\circ} \mathrm{S}$ ) and chlorite to the south. Kaolinite only occurs in minor amounts (Fig. 6E). Global clay mineral distribution maps (Griffin et al. 1968; Windom 1976) indicate higher illite, lower smectite, and partly lower chlorite contents for the appropriate area than our data show.

Smectite in our study area is thought to be primarily of detritic (including continental neoformation) and only subordinately of authigenic origin. The detritic character of smectites at similar active continental margin settings (Japan trench) has been noted by various authors (e.g., Aoki et al. 1974; Chamley and Debrabant 1989; Aoki and Kohyama 1992). Smear slide analyses of our samples showed only minor amounts of mainly unaltered volcanic glass. This rules out any significant authigenic smectite supply by halmyrolytic weathering of volcanic glass. High smectite concentrations and crystallinities in the northernmost part $\left(27^{\circ} \mathrm{S}\right.$ to $\left.30^{\circ} \mathrm{S}\right)$ of the study area may reflect continental smectite neoformation. Warm and semiarid to arid climatic conditions, as in northern Chile, enhance this process (Chamley 1989). Slightly lower amounts of smectite in the $33^{\circ} \mathrm{S}$ and $35^{\circ} \mathrm{S}$ transects are in contrast to more abundant volcanic source rocks in the hinterland which should increase smectite concentrations as volcanics preferentially alter to smectite (Chamley 1989). The comparatively low smectite abundance probably reflects less smectite neoformation in this area due to a more humid climate. Lowest smectite contents, occurring nearshore, might be attributed to differential settling processes (see below). In the southernmost part $\left(41^{\circ} \mathrm{S}\right.$ to $\left.43^{\circ} \mathrm{S}\right)$ the highest smectite contents occur associated with poor crystallinities here. Source-rock composition remains favorable for smectite formation and poor crystallinities are characteristic of humid-temperate climatic conditions (Chamley 1989) as found there.

Illite contents, revealing a gradual southward decrease, reflect mainly the source-rock composition along the Chilean continental margin. Highest values in the northern part coincide with more abundant plutonic source rocks. The only measured sedimentological parameter which reflects primarily the strong climatic zonation of Chile is the illite crystallinity, which is thought to indicate the chemical weathering intensity in the source areas (Singer 1984; Chamley 1989). Therefore, better crystallized illite in the northernmost and southernmost transects (Fig. 6F) results from low chemical weathering activity in this areas due to arid climate in the north and cool temperate climate with heavy rainfall in the south (Fig. 1). Poor illite crystallinities in the $33^{\circ} \mathrm{S}$ and $35^{\circ} \mathrm{S}$ transects indicate stronger chemical weathering intensity which corresponds to a relatively humid and warm climate in this area. However, immature bulk-mineral assemblages seem to contradict this finding. Apparently chemical weathering is sufficient for a strong hydrolyzation of illite (resulting in poor crystallinities), but not for significant alteration and dissolution of minerals of 
the source rocks due to high erosion rates and short transport distances.

Chlorite derives mainly from low-grade metamorphic and basic igneous source rocks but is easily destroyed by chemical weathering processes and therefore concentrated in high latitudes, especially in the southern oceans (Chamley 1989; Weaver 1989; Hillier 1995). In our study area chlorite contents are controlled primarily by regional variations in the source-rock composition. A generally high abundance south of $33^{\circ} \mathrm{S}$, with maximum values in the $35^{\circ}$ to $36^{\circ} \mathrm{S}$ area, correlates to the abundance of basic igneous and metamorphic source rocks as described previously. The high iron content of chlorite, reaching its maximum in the same area, indicates a primarily basic igneous origin here, because more iron-rich chlorites often form from hydrothermally altered ferromagnesian minerals of basic source rocks (Deer et al. 1992). Therefore, iron-poorer chlorite of the southernmost transect is mainly of metamorphic provenance.

The observed minor amounts of kaolinite can be derived from the erosion of fossil kaolinite from sediments and paleosoils or transportation by oceanic currents (e.g., GUC or PCCC) from equatorial areas. Under the present climatic conditions kaolinite should not be formed in Chile as the neoformation of this mineral requires intense chemical weathering intensities as in humid tropical and subtropical climates (Chamley 1989; Weaver 1989; Hillier 1995).

The regional clay mineralogical patterns in our study area are clearly related to source-rock composition and, subordinately, to climate. However, differential settling processes, due to distinct size distributions of the clay mineral groups, can influence significantly the clay mineral distribution along continental margins (e.g., Gibbs 1977; Carson and Arcaro 1983). Differential settling might have accounted for the generally minor variations within the slope transects (i.e., depth dependence of smectite, especially $33^{\circ} \mathrm{S}$ transect). This process also explains the totally differing clay mineral assemblage of the shelf and upper-slope samples of the $36^{\circ} \mathrm{S}$ transect (i.e., very low smectite contents; Table 3). The more offshore samples comprise higher smectite amounts which might indicate that this mineral is held in suspension and settling begins further offshore. The source-rock composition as well as the bulk mineralogy of the surface sediments do not differ significantly from the adjacent $35^{\circ} \mathrm{S}$ transect.

\section{Samples from areas west of the Peru-Chile trench}

Surface sediments from areas west of the Peru-Chile Trench contain significant amounts of terrigenous fine silt. This material might reach the pelagic areas by eolian transport in the northern part of the study area as also proposed for northern Chile and Peru (Krissek et al. 1980). In the southern part the trench does not display a barrier for the seaward transport of terrigenous material due to its thick sediment infill. Therefore, distal turbidity currents can reach the oceanic parts west of the trench axis and deposit the silty material. In this area prevailing onshore westerly winds prevent eolian sediment input.

The bulk- and clay mineral assemblages do not differ significantly from the adjacent slope samples and the regional patterns of the slope samples are particularly well recorded for the bulk mineralogy (Fig. 5E-F) and for the illite crystallinity (Fig. 6F). The southernmost more offshore samples $\left(43^{\circ} \mathrm{S}, 80^{\circ} \mathrm{W}\right)$ contain less smectite and high chlorite and illite amounts. Clay mineral studies off southern Chile at ca. $42^{\circ} \mathrm{S}-55^{\circ} \mathrm{S}$ (Siegel et al. 1981) and at ca. $46^{\circ} \mathrm{S}$ (Kurnosov et al. 1995) revealed illite- and chlorite-dominated assemblages. Therefore, the differing clay mineralogy of these offshore samples might indicate lateral input from southern areas or pelagic areas to the west as the Antarctic Circumpolar Current approaches South America in this area (see Oceanographic setting).

\section{Conclusion}

The sedimentation of terrigenous material on the continental slope off Chile is dominated by hemipelagic processes. Climate affects the mode of sediment input (eolian vs fluvial) and the grain size of the source material (physical vs chemical weathering). The latter is also influenced by the primary grain size of source rocks.

The original source-rock signal of the different geological terranes of Chile between $25^{\circ} \mathrm{S}$ and $43^{\circ} \mathrm{S}$ is best preserved in bulk mineralogical data of slope sediments. Bulkmineral assemblages are not significantly altered by continental chemical weathering because of high morphological gradients and short transport distances throughout the study area. Climate does not influence the bulk mineralogy by significant modifications of the weathering regime but by its impact on the continental hydrology which controls the relative source-rock contribution of the Coastal Range and Andes, respectively.

The relative abundance of clay minerals is strongly affected by variations of source-rock compositions on the continent. Climate influences the continental neoformation of smectite and especially the illite crystallinity. The latter reflects the latitudinal variations of the weathering activity in Chile corresponding to the climatic zonation. Clay mineral assemblages have not been altered significantly by marine authigenic processes. Differential settling generally only plays a minor role for the distribution of clay minerals across the slope but significantly affects the clay mineral assemblages on the shelf and uppermost slope of the $36^{\circ} \mathrm{S}$ transect.

Bulk and clay mineralogical parameters of sediments from areas west of the Peru-Chile trench generally reveal similar regional distribution patterns as the slope samples, indicating that the trench does not display a barrier for the seaward transport of terrigenous material. 
Acknowledgements We thank the captain and crew of RV SONNE for their excellent help in collecting the samples. Analytical assistance was provided by B. Diekmann, G. Kuhn, R. Fröhlking, S. Janisch, and H. Rhodes at the Alfred Wegener Institute in Bremerhaven. B. Diekmann also gave many helpful comments on a previous version of the manuscript. We are grateful to Prof. Wetzel and an anonymous reviewer for prompt and constructive reviews. Financial support was provided by the Deutsche Bundesministerium für Bildung und Forschung through funding the project CHIPAL (03G0102 A).

\section{References}

Aoki S, Kohyama N (1992) Modern sedimentation in the Japan Trench: implications of the mineralogy and chemistry of clays sampled from sediment traps. Mar Geol 108: 197-208

Aoki S, Oimuma K, Sudo T (1974) The distribution of clay minerals in Recent sediments of the Japan Sea. Deep-Sea Res 21: 299-310

Baba J (1986) Terrigenous sediments in two continental margin environments: western South America and the Gulf of California. Oregon State University, Oregon

Biscaye PE (1965) Mineralogy and sedimentation of recent deep-sea clay in the Atlantic Ocean and adjacent seas and oceans. Geol Soc Am Bull 76: 803-832

Boltovskoy E (1976) Distribution of Recent foraminifera of the South America region. In: Hedley RH, Adams CG (eds) Foraminifera. Academic Press, New York, pp 171-236

Carson B, Arcaro NP (1983) Control of clay mineral stratigraphy by selective transport in Late Pleistocene-Holocene sediments of northern Cascadia basin-Juan de Fuca abyssal plain: implication for studies of clay mineral provenance. J Sediment Petrol 53: 395-406

Chamley H (1989) Clay sedimentology. Springer, Berlin Heidelberg New York

Chamley H, Debrabant P (1989) Continental and marine influences expressed by deep-sea sedimentation off Japan (Kaiko Project). Palaeogeogr Palaeoclimatol Palaeoecol 71: 49-69

Clayton T, Kemp AES (1990) Clay mineralogy of Cenozoic sediments form the Peruvian continental margin: Leg 112. Proc ODP Sci Results 112: 59-77

Deer WA, Howie RA, Zusman J (1992) An introduction to the rockforming minerals. Longman, Essex, England

Emmermann R, Lauterjung J (1990) Double X-Ray analysis of cuttings and rock flour: a powerful tool for rapid and reliable determination of borehole lithostratigraphy. Sci Drill 1: 269-282

Folk RL, Ward W (1957) Brazos River bar: a study in the significance of grain size parameters. J Sediment Petrol 27: 3-26

Fossing H, Gallardo VA, Jørgensen BB, Hüttel M, Nielsen LP, Schulz H, Canfield DE, Forster S, Glud RN, Gundersen JK, Küver J, Ramsing NB, Teske A, Thamdrup B, Ulloa O (1995) Concentration and transport of nitrate by the mat-forming sulphur bacterium Thioploca. Nature 374: 713-715

Friedman GM, Sanders JE (1978) Principles of sedimentology. Wiley, New York

Gibbs RJ (1977) Clay mineral segregation in the marine environment. J Sediment Petrol 47: 237-243

Griffin JJ, Windom H, Goldberg ED (1968) The distribution of clay minerals in the World Ocean. Deep-Sea Res 15: 431-459

Hebbeln D, Wefer G et al. (1995) Cruise Report of R/V SONNE Cruise 102, Valparaiso-Valparaiso, 9 May to 28 June 1995. Universität Bremen, Bremen, $126 \mathrm{pp}$

Heusser CJ (1984) Late Quaternary climates of Chile. In: Vogel JC (ed) Late Cenozoic palaeoclimates of the southern hemisphere. Balkema, Rotterdam, pp 59-83

Hillier S (1995) Erosion, sedimentation and sedimentary origin of clays. In: Velde B (ed) Origin and mineralogy of clays. Springer, Berlin Heidelberg New York, pp 162-214

Ingle JC, Keller G, Kolpack RL (1980) Benthic foraminiferal biofacies, sediments and water masses of the southern Peru-Chile Trench area, southeastern Pacific Ocean. Micropal 26: 113-150
Johnson DR, Fonseca T, Sievers H (1980) Upwelling in the Humboldt Coastal Current near Valparaiso, Chile. J Mar Res 38: 1-15

Jones KPN, McCave IN, Patel PD (1988) A computer-interfaced sedigraph for modal size analysis of fine-grained sediment. Sedimentology 35: 163-172

Jordan TE, Isacks BL, Allmendinger RW, Brewer JA, Ramos VA, Ando CJ (1983) Andean tectonics related to geometry of subducted Nazca plate. Geol Soc Am Bull 94: 341-361

Krissek LA, Scheidegger KF, Kulm LD (1980) Surface sediments of the Peru-Chile continental margin and the Nazca plate. Geol Soc Am Bull 91: 321-331

Kurnosov V, Murdmaa I, Chanov N, Chudaev O, Eroshchev-Shak V, Shterenberg L (1995) Mineralogy of sediments from the Chile triple junction. Proc ODP Sci Results 141: 95-104

Lowrie A, Hey R (1981) Geological and geophysical variations along the western margin of Chile near lat $33^{\circ}$ to $36^{\circ} \mathrm{S}$ and their relation to Nazca plate subduction. Geol Soc Am Mem 154: 741-754

Miller A (1976) The climate of Chile. In: Schwerdtfeger W (ed) World survey of climatology, vol 12. Elsevier, Amsterdam, pp 113-145

Milliman JD, Rutkowski C, Meybeck M (1995) River discharge to the sea: a global river index (GLORI). NIOZ, Texel, The Netherlands

Moore DM, Reynolds RC (1989) X-ray diffraction and the identification and analysis of clay minerals. Oxford University Press, Oxford

Müller G (1967) Methods in sedimentary petrology. In: Engelhardt W von, Füchtbauer H, Müller G (eds) Sedimentary petrology. Schweizerbart'sche Velagsbuchhandlung, Stuttgart

Paskoff RP (1977) Quaternary of Chile: the state of research. Quaternary Res 8: 2-31

Petschick R, Kuhn G, Gingele F (1996) Clay mineral distribution in surface sediments of the South Atlantic: sources, transport and relation to oceanography. Mar Geol 130: 203-229

Reading HG, Collinson JD (1996) Clastic coasts. In: Reading HG (ed) Sedimentary environments: processes, facies and stratigraphy. Blackwell, Oxford, pp 154-231

Rosato VJ, Kulm LD (1981) Clay mineralogy of the Peru continental margin and adjacent Nazca plate: implications for provenance, sea level changes, and continental accretion. Geol Soc Am Mem 154: $545-568$

Ruiz C, Corvalan J (1968) Mapa geologico de Chile scale 1:1,000,000. Santiago Instituto de Investigaciones Geologicas, Santiago, Chile

Sarnthein M, Thiede J, Pflaumann H, Erlenkeuser H, Fütterer D, Koopmann D, Lange H, Seibold E (1984) Atmospheric and oceanic circulation patterns off Northwest Africa during the past 25 Million years. In: Rad H von, Hinz K, Sarnthein M, Seibold E (eds) Geology of the Northwest African Continental Margin. Springer, Berlin Heidelberg New York, pp 584-604

Scheidegger KF, Krissek LA (1982) Dispersal and deposition of eolian and fluvial sediments off Peru and northern Chile. Geol Soc Am Bull 93: 150-162

Scholl DW, Christensen MN, Huene R von, Marlow MS (1970) Peru-Chile Trench. Sediments and sea-floor spreading. Geol Soc Am Bull 81: 1339-1360

Shaffer G, Salinas S, Pizarro O, Vega A, Hormazabal S (1995) Currents in the deep ocean off Chile $\left(30^{\circ} \mathrm{S}\right)$. Deep-Sea Res 42: $425-436$

Shepard FP (1954) Nomenclature based on sand-silt-clay ratios. J Sediment Petrol 34: 151-158

Siegel FR, Pierce JW, Kostick DS, Ronca LB (1981) Suspensates and bottom sediments in the Chilean archipelago. Modern Geol 7: $217-229$

Singer A (1984) The paleoclimatic interpretation of clay minerals in sediments: a review. Earth Sci Rev 21: 251-293

Stein R (1985) Rapid grain-size analyses of clay and silt fraction by Sedigraph 5000D: comparison with Coulter Counter and Atterberg methods. J Sediment Petrol 55: 590-615

Stow DAV (1986) Deep clastic seas. In: Reading HG (ed) Sedimentary environments and facies. Blackwell, Oxford, pp 398-444 
Strub PT, Mesias JM, Montecino V, Ruttlant J, Salinas S (1998) Coastal ocean circulation off western South America. In: Robinson AR, Brink KH (eds) The sea: the global coastal ocean, regional studies and syntheses. Wiley, New York

Summerhayes CP, Milliman JD, Briggs SR, Bee AG, Hogan C (1976) Northwest African shelf sediments: influence of climate and sedimentary processes. J Geol 84: 277-300

Syvitszki JPM (1991) Principles, methods and application of particle size analysis. Press Syndicate of the University of Cambridge, Cambridge
Thornburg T, Kulm LD (1987a) Sedimentation in the Chile Trench: depositional morphologies, lithofacies and stratigraphy. Geol Soc Am Bull 98: 33-52

Thornburg T, Kulm LD (1987b) Sedimentation in the Chile Trench: petrofacies and provenance. J Sediment Petrol 57: 55-74

Weaver CE (1989) Clays, muds and shales. Elsevier, Amsterdam

Windom HL (1976) Lithogenous material in marine sediments. In: Riley JP, Chester R (eds) Chemical oceanography. Academic Press, New York, pp 103-135

Zeil W (1986) Südamerika. Enke, Stuttgart 